WORKING PAPER \#589a

PRINCETON UNIVERSITY

INDUSTRIAL RELATIONS SECTION

May 2015

Version: October 26, 2016

http://arks.princeton.edu/ark:/88435/dsp01z890rw73j

\title{
Employment, Hours and Earnings Consequences of Job Loss: U.S. Evidence from the Displaced Workers Survey ${ }^{1}$
}

Henry S. Farber

Princeton University

\begin{abstract}
The Great Recession from December 2007 to June 2009 is associated with a dramatic weakening of the labor market from which it has recovered only slowly. I use data from the Displaced Workers Survey (DWS) from 1984-2016 to investigate the incidence and consequences of job loss from 1981-2015. In particular, the 2010-2016 DWSs provide a window through which to examine the experience of job losers in the Great Recession and its aftermath and to compare their experience to that of earlier job losers. These data show a record high rate of job loss in the Great Recession, with almost one in six workers reporting having lost a job in the 2007-2009 period, that slowly returned to pre-recession levels in the 2011-2015 period. The employment consequences of job loss are also very serious during this period with very low rates of reemployment and difficulty finding fulltime employment during the Great Recession and its aftermath. The reduction in weekly earnings for those full-time job losers during the 2007-2015 period who were able to find new full-time employment are relatively small, even for those displaced since 2008. In fact, a substantial minority of these job losers report earning more on their new job than on the lost job. Most of the cost of job loss comes from difficulty in finding new full-time employment. [JEL Classification: J63]
\end{abstract}

${ }^{1}$ Industrial Relations Section, Firestone Library, Princeton University, Princeton, NJ 08544. Phone: (609)258-4044. email: farber@princeton.edu. An earlier version of this paper was prepared for a conference, "Essays on the Economics of Education, Training, and Labor Markets: A Festshrift in Honor of Robert LaLonde," held at the Federal Reserve Bank of Chicago, April 17-18, 2015. 


\section{Introduction}

The Great Recession from December 2007 to June 2009 is associated with tremendous job destruction and costly adjustment for those workers whose jobs were lost. The labor market recovered very slowly, and by some measures the recovery is not yet complete, even more than 6 years later. The unemployment rate remained stubbornly high for several years, durations of unemployment continue to be unprecedentedly long, part-time employment rates remain elevated, and wage growth is sluggish. In this study I use the Displaced Workers Surveys (DWS), administered every two years from 1984-2016 as a supplement to the Current Population Survey (CPS), to examine the experience of job losers during and after the Great Recession and to compare their experience to that of earlier job losers. The January 2010 DWS is of particular interest since it covers job loss during the period of the Great Recession (2007-2009), and the succeeding three DWSs (2012, 2014, and 2016) shed important light on the experience of post-recession job losers in a labor market that was still recovering from the Great Recession. ${ }^{1}$

The central focus of my analysis is on the employment, hours, and earnings losses suffered by full-time job losers. ${ }^{2}$ I distinguish three sources of earnings loss among full-time job losers:

1. Non-employment - Full-time job losers who are not reemployed suffer a complete loss of earnings mitigated to some extent by unemployment insurance benefits.

2. Part-time reemployment - Full-time job losers who take part-time jobs suffer a partial loss of earnings, both as a result of lower work hours and the lower average hourly earnings generally received for part-time work.

3. Lower earnings for full-time work - Full-time job losers who do find a new full-time job may have reduced earnings on their new job.

\footnotetext{
${ }^{1}$ Examples of earlier work using the DWS includes Farber (1997, 2013), Podgursky and Swaim (1987), Kletzer (1989), Topel (1990), Gardner (1995), Neal (1995), Hipple (1999), and Schmeider and von Wachter (2010). See Fallick (1996) and Farber (2004) for reviews of the earlier literature.

${ }^{2}$ Analyses of the cost of job loss based solely on employment and earnings of the sort I present here abstracts from the value of non-market time that is "enjoyed" by the unemployed. This is a factor stressed by some recent work in macroeconomics (e.g., Hagedorn, M., and I. Manovskii (2008) and Chodorow-Reich and Karabarbounis (2016)). Additionally, analyses focused solely on employment and earnings ignore nonincome related (perhaps psychological and social) costs of job loss. In other words, my analysis is about earnings losses rather than utility losses suffered by displaced workers or any losses that are external to the individual.
} 
I use the information in the DWS to decompose earnings losses for full-time job losers into components due to each of these three sources.

The study of worker displacement, both through plant closings, large layoffs, and smaller events is an important focus of work in recent years. While much earlier work uses data from the DWS, a body of more recent work builds on the seminal study of Jacobsen, LaLonde, and Sullivan (1993) using adminstrative data (e.g., Couch and Placzek, 2010; Davis and von Wachter, 2011; Song and Von Wachter, 2014). The work using the DWS and the work using administrative data are complementary in the sense that they address related but somewhat different dimensions of the cost of job loss. The DWS is well suited for the study of short run employment outcomes of job losers and declines in weekly earnings for reemployed job losers. In the context of this study, the DWS allows direct analysis of the role of hours of work (non-employment and part-time employment) in accounting for earnings declines after job loss. In contrast, the administrative data, usually quarterly data from state unemployment insurance records or Social Security Administration data, can be used to study earnings losses over longer periods of time and to calculate the total dollar value of lost income, but it cannot be used to study hours of work or movements in weekly earnings.

I begin in the next section with a brief presentation of movements over time in key labor market indicators derived from the CPS. These include the unemployment rate, the average duration of unemployment spells, the employment-population ratio, and key monthly transition rates between labor force states (exit rates from employment and unemployment). These highlight the severity of the Great Recession and the slow recovery. I also present data on part-time employment rates and transitions rates between labor force states that make distinctions between full-time and part-time employment in order to set the stage for the later analysis. In section 3, I describe the data I use from the DWS and discuss measurement and data issues relevant to the analysis of job loss. Section 4 contains an analysis of the incidence of job loss. Next, I analyze the consequences of job loss in several dimensions. I begin in section 5 with an investigation of post-displacement labor force status, employment probabilities, and the likelihood of part- and full-time employment. In section 6, I consider the decline in weekly earnings due to displacement. This section includes a decomposition of the decline in weekly earnings due non-employment, part-time employment, and any decline in earnings suffered by those job losers who are reemployed full-time. In section 7 , I investigate the extent to which some full-time job losers may, in fact, be reemployed in a better (higher paying) job than the lost job. Section 8 contains a discussion of the findings and concluding remarks. 




Figure 1: Civilian Unemployment Rate, by quarter, seasonally adjusted

\section{Overview of Labor Market Conditions}

Figure 1 contains a plot of the quarterly seasonally adjusted civilian unemployment rate from 1978 through 2016q2. ${ }^{3}$ There has been substantial variation in labor market conditions over the period covered by the DWS (1981-2015), and substantial cyclical variation in the unemployment rate is evident. The early 1980s saw a sharp increase in the unemployment rate to almost 11 percent as a consequence of the July 1981 - November 1982 recession. This increase was followed by a long decline in during the remainder of the 1980s and then by milder cyclical variation followed by a long decline to about 4 percent in early 2000. After the comparatively mild recession in 2001, the unemployment rate again declined to about 4.5 percent in 2007 before rising sharply as a consequence of the Great Recession.

The high unemployment rate experienced in the Great Recession was slow to return to pre-recession levels. The seasonally-adjusted unemployment rate peaked at 10.0 percent in the first quarter of 2010, was still at 9.5 percent in the fourth quarter of 2010, more than

\footnotetext{
${ }^{3}$ The seasonally-adjusted unemployment rates that I refer to in the text and in the figures are based on my own calculations using the basic CPS public use files available for this period. I weight by the CPS final sampling weights. In order to seasonally adjust a series $Y_{t}$ with overall mean $\bar{Y}$, I regress $Y_{t}$ on a complete set of seasonal dummy variables and calculate the residuals, $e_{t}$. I then compute the seasonally-adjusted series as $Y_{t}^{s a}=\bar{Y}+e_{t}$.
} 


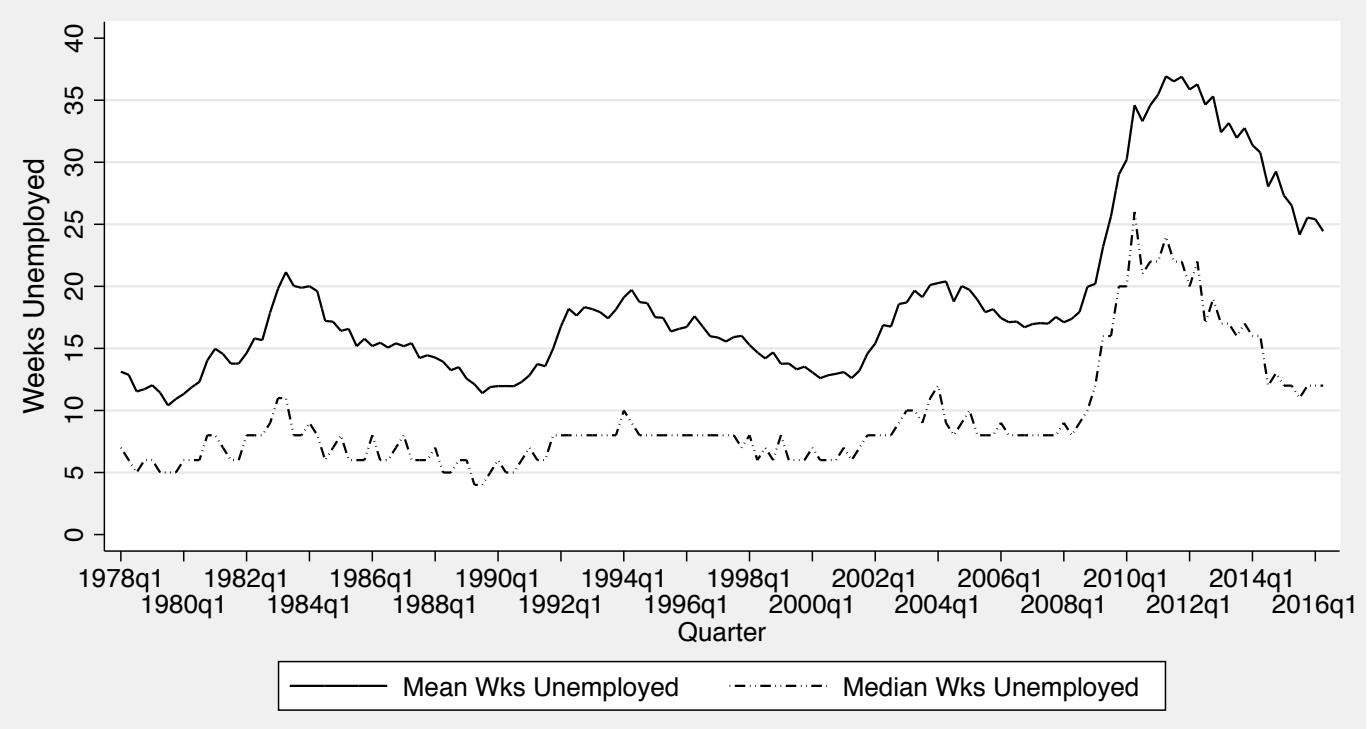

Figure 2: Duration of Unemployment Spells, by quarter, seasonally adjusted

one full year after the "official" end of the recession in June 2009. ${ }^{4}$ The unemployment rate has fallen steadily since 2010 to about 5 percent in mid-2016 though it has not yet fallen to its pre-recession level.

A related concern is the unprecedentedly long average duration of unemployment spells. This is illustrated in figure 2, which shows both the mean and median seasonally adjusted duration of unemployment for spells in progress, quarterly from 1978-2016q2. This figure clearly shows the counter-cyclical nature of unemployment duration. The mean unemployment rate reached about 20 weeks in the three earlier recessions show but rose to 37 weeks in the Great Recession. The figure further indicates a continuing increase in mean unemployment duration into 2011 (mean duration 36.9 weeks in 2011Q4) before falling somewhat to about 25 weeks early in 2016. The median showed a similar pattern, reaching about 10 weeks in earlier recessions but increasing to 25 weeks in the most recent recession. More than 6 years after end of the Great Recession, both mean and median duration of unemployment spells in progress remain above anything seen prior to the Great Recession.

These high unemployment rates and long spell durations reflect in large measure changes

4 This is the NBER dating of the recession. See http://www.nber.org/cycles.html and NBER (2010) for more information of the NBER business cycle dating procedure. The labor market historically lags the NBER dates, which are based largely on GDP growth. For example, the NBER dated the end of the Great Recession in June 2009 while the unemployment rate reported by the U.S. Bureau of Labor Statistics peaked in October 2009. 


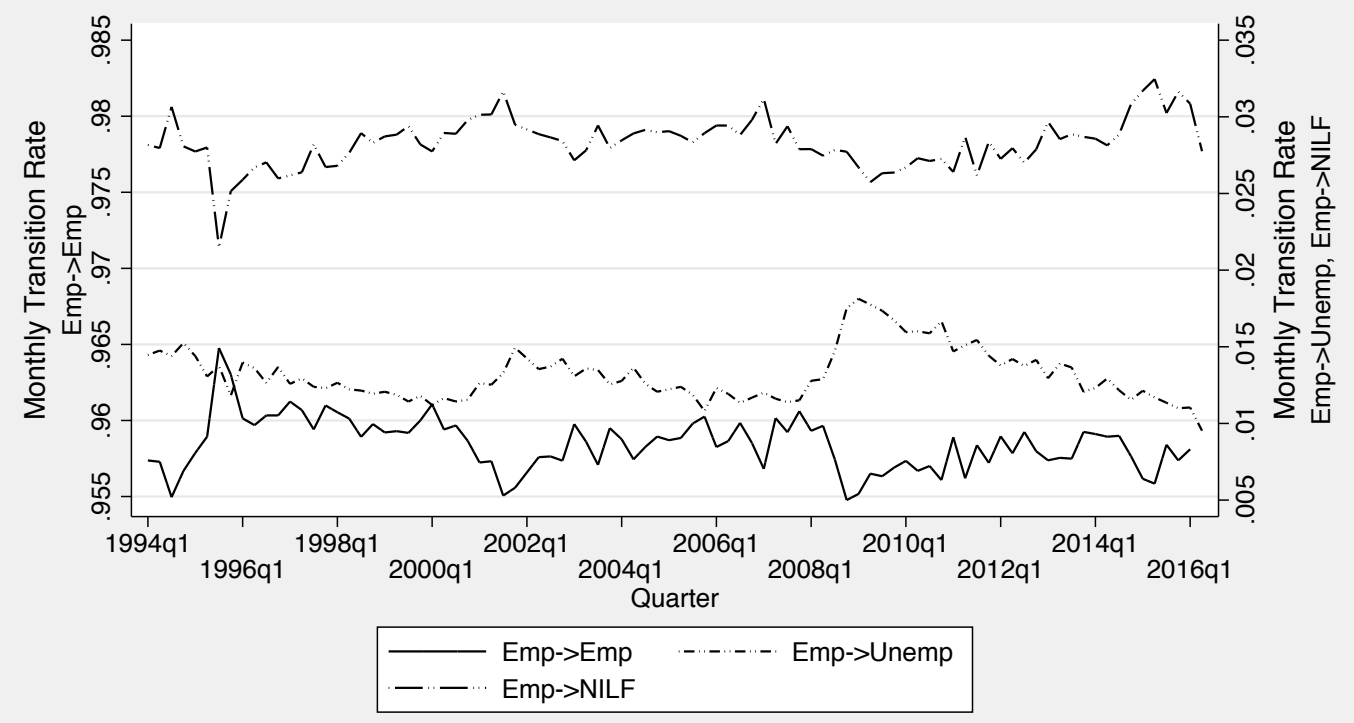

Figure 3: Monthly Flows from Employment, Matched CPS

in flows between labor force states. Figure 3 uses month-to-month matched CPS data from 1994 onward to show flow rates from "employed" (E) to "employed" (E), "unemployed" (U), and "not in the labor force" (NILF). The E-E flow (left axis scale), which represents the probability that an employed person remains employed, drops from 0.96 to 0.955 in 2008 and slowly recovers by late 2014. While this sounds small, consider the complement. The probability of leaving employment increased from 0.04 to 0.45 , an increase of 12.5 percent. Virtually all of this was movement from employment to unemployment (rather than exit from the labor force). The $\mathrm{E}-\mathrm{U}$ flow rate (right axis scale) increased from about .011 in late 2007 to .018 by early 2009 (an increase of 63 percent) and slowly decreased through 2015 .

Figure 4 shows flow rates from "unemployed" to each of the three labor force states. The U-E flow, which represents the probability that an unemployed person finds employment, dropped from 0.27 in late 2007 to about 0.16 to 0.17 in 2009 and 2010 (a drop of 37 percent) before partially recovering to 0.24 by late 2015 . The probability of remaining unemployed (U-U flow) increased from 0.5 in late 2007 to 0.65 in late 2009 (an increase of 30 percent) before recovering through late 2015 .

The labor force flows shown in figures 3 and 4 are consistent with the sharp elevation and slow declines in the unemployment rate and unemployment durations shown in figures 1 and 2. The Great Recession was a period of serious disruption of employment relationships, and it is clear that unemployed workers had a difficult time finding new jobs. The dynamics 


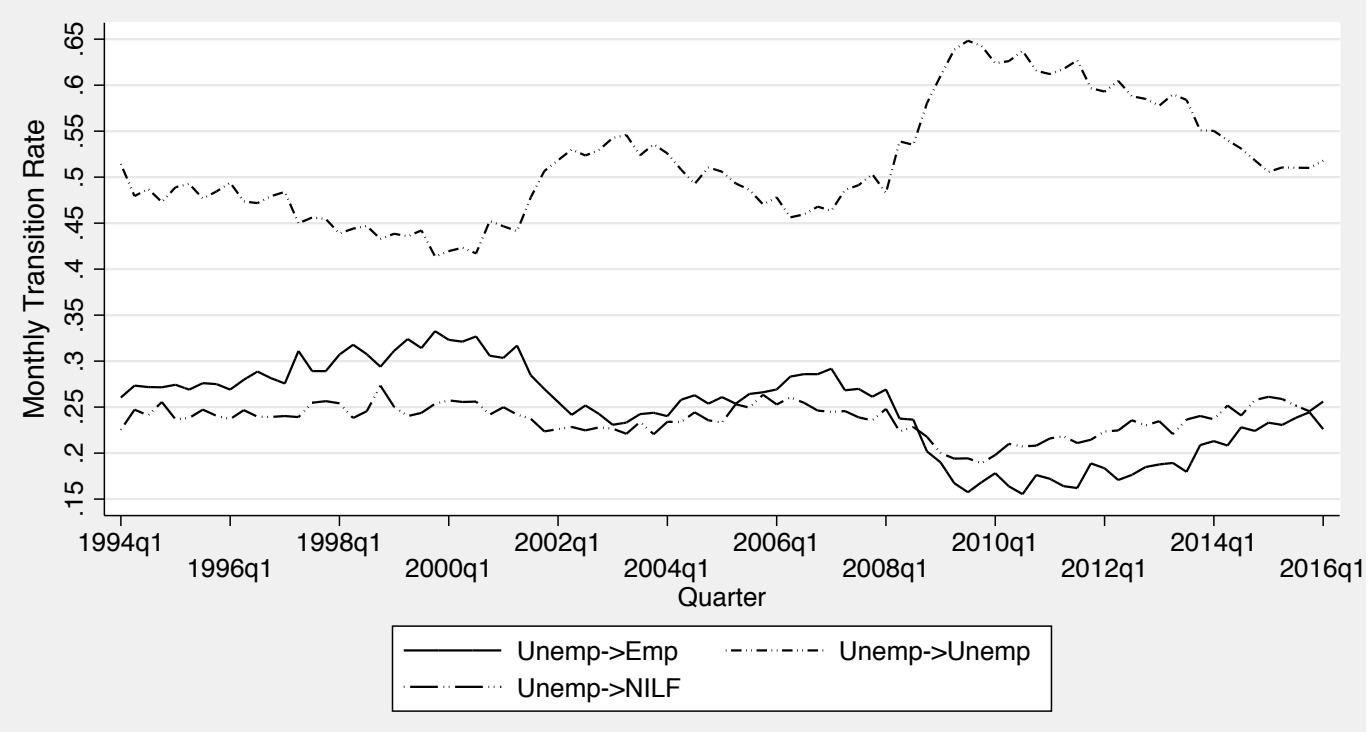

Figure 4: Monthly Flows from Unemployment, Matched CPS

of unemployment in the Great Recession and its aftermath were fundamentally different from unemployment dynamics in earlier recessions, where the changes in the unemployment rate, unemployment durations, and flows out of employment and unemployment were less pronounced and recovered to pre-recession levels relatively quickly.

\subsection{Part-Time Employment}

Part-time work is defined in the CPS as fewer than 35 hours per week. Part-time workers are queried on the reason for working fewer than 35 hours and can be classified as "part-time for noneconomic reasons" (also referred as "voluntary part-time") and "part-time for economic reasons" (also referred to as "involuntary part-time"). The voluntary part-time are those who are part-time as the result of a labor supply decision based on personal reasons such as family obligations, school enrollment, or simply desiring fewer than full-time hours. The involuntary part-time are workers who report that they would like to work full-time but cannot find a full-time job or their current job has cut back hours. ${ }^{5}$ The 1994 CPS redesign changed the battery of questions about hours of work on the current job in a way that may have raised the fraction of workers reporting they are currently working part time, both over

\footnotetext{
${ }^{5}$ See Valletta, Bengali, and van der List (2015) for a discussion of measures of part-time employment and an analysis of involuntary part-time employment.
} 


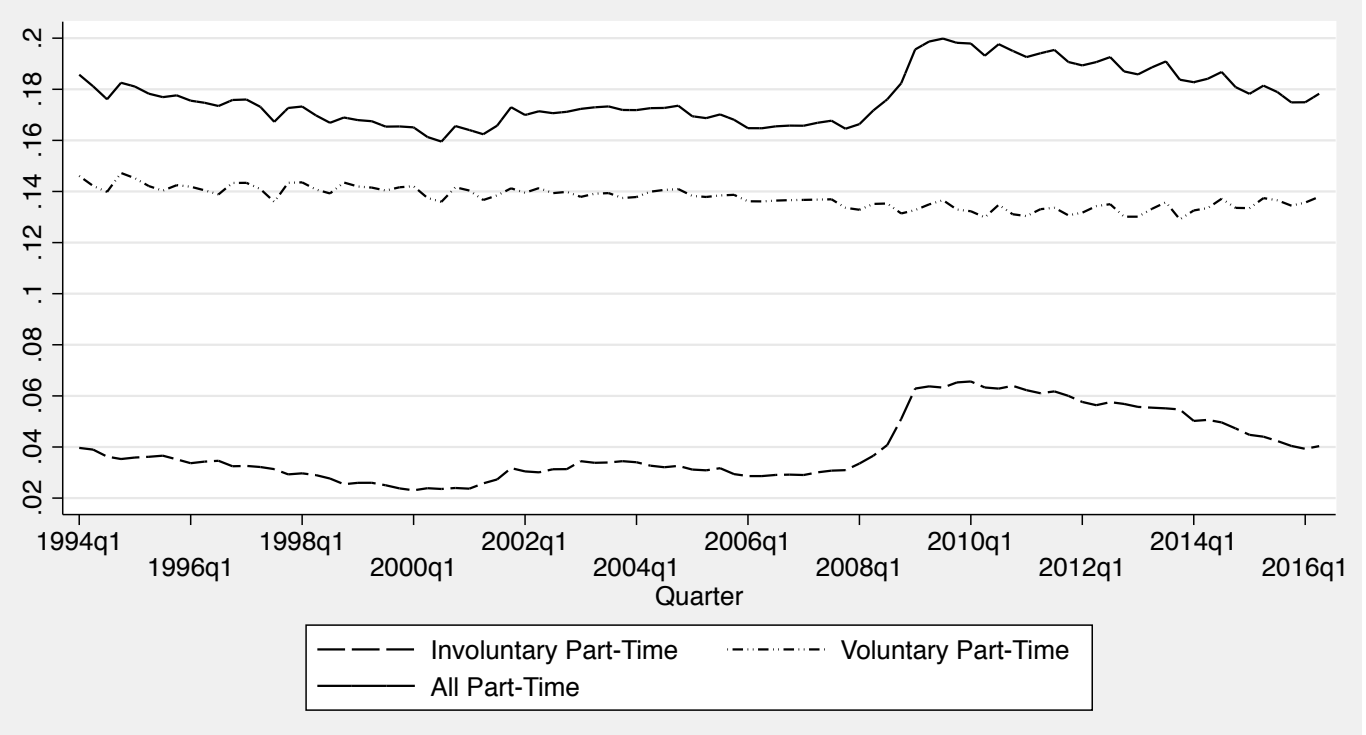

Figure 5: Part-Time Shares of Total Employment, seasonally adjusted, 1994-2016Q2

all and by specific reason. ${ }^{6}$ For this reason, I limit my presentation and analysis of part-time work in this descriptive section to the post-1994 period.

Figure 5 shows the seasonally-adjusted time series of the part-time share of employment from 1994-2016Q2. The part-time share of employment declined slowly from about 18.5 percent in 1994 to 16.5 percent in 2007, before spiking in the Great Recession to 20 percent (2009Q3). The figure also shows the times series of the part-time share broken down by voluntary and involuntary part-time work. It is clear that the increase in the overall parttime share is due entirely to a very large increase (a more than doubling) in the share of involuntary part-time, from 3 percent in 2007 to 6.4 percent in 2010. This could be a result of "work sharing," where employers who suffered a drop in product demand cut hours per worker rather than lay off workers or it could be a result of job losers who desire full-time work able to find only part-time jobs.

Figure 6 shows flow rates from full-time employment to the various full-time and parttime employment categories as well as the flow to unemployment. The FT-FT flow rate (top line, left axis scale) shows a 1.5 percentage point decline in the Great Recession from 92.6 percent in 2007 to 91.1 percent in late 2008. The FT-U flow rate (right axis scale) increased by 0.3 percentage points, from 1 percent to 1.3 percent over the same period, illustrating

\footnotetext{
${ }^{6}$ The effect of the CPS redesign on measurement of hours of work is discussed in detail by Polivka and Miller (1998).
} 


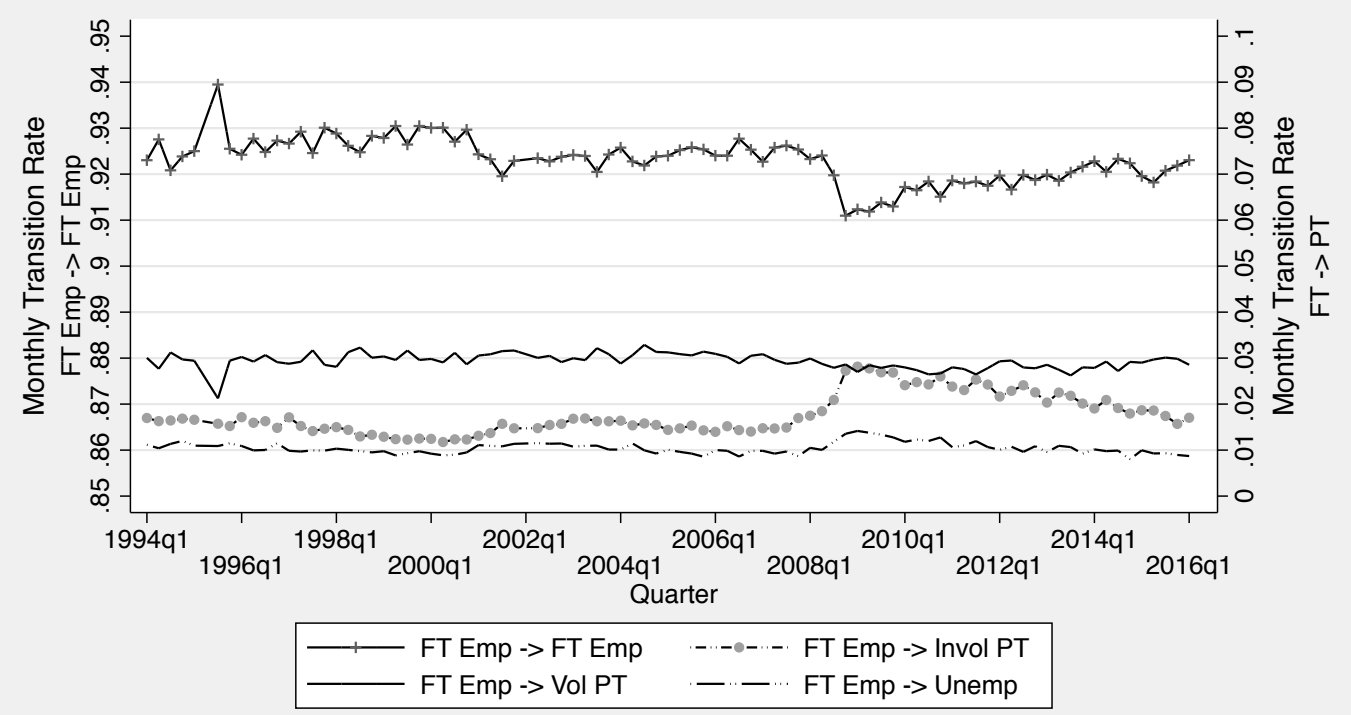

Figure 6: Monthly Flows from Full-Time Employment, Matched CPS

the increased job loss rate of full-time workers in the Great Recession. Interestingly, the FTinvolPT flow rate (right axis scale) increased by 1.1 percentage points, from 1.5 percent in 2007 to 2.6 percent in late 2010. Note that these "new" part-time workers may be full-time job losers who took a part-time job or they may be full-time workers whose employers cut their hours. But there were clearly substantially work hours losses in the Great Recession that go well beyond the loss of work suffered by the unemployed.

In order to examine the hours of jobs taken by the unemployed, figure 7 shows flow rates from unemployment to the various full-time and part-time employment categories as well as the flow to unemployment. Not surprisingly, the unemployment retention rate (top line, right axis scale) is substantial and rises dramatically in the Great Recession from about 45 percent in 2007 to over 60 percent in 2010. Much of this is accounted for by a decline in the flow from unemployment to full-time employment from about 18 percent in 2007 to less than 10 percent in 2010 (left axis scale). There is very little change in the flow from unemployment to involuntary part-time employment (left axis scale), which holds steady at about 5 percent. Interestingly, there is a substantial decline in the flow rate from unemployment to voluntary part-time employment, from about 6 percent in 2007 to about 3 percent in 2010.

A reasonable interpretation of these patterns is that in the Great Recession a higher fraction of unemployed workers seeking full-time jobs found part-time jobs (rather than full-time jobs) and that this offset the general decline in the availability of both full- and 


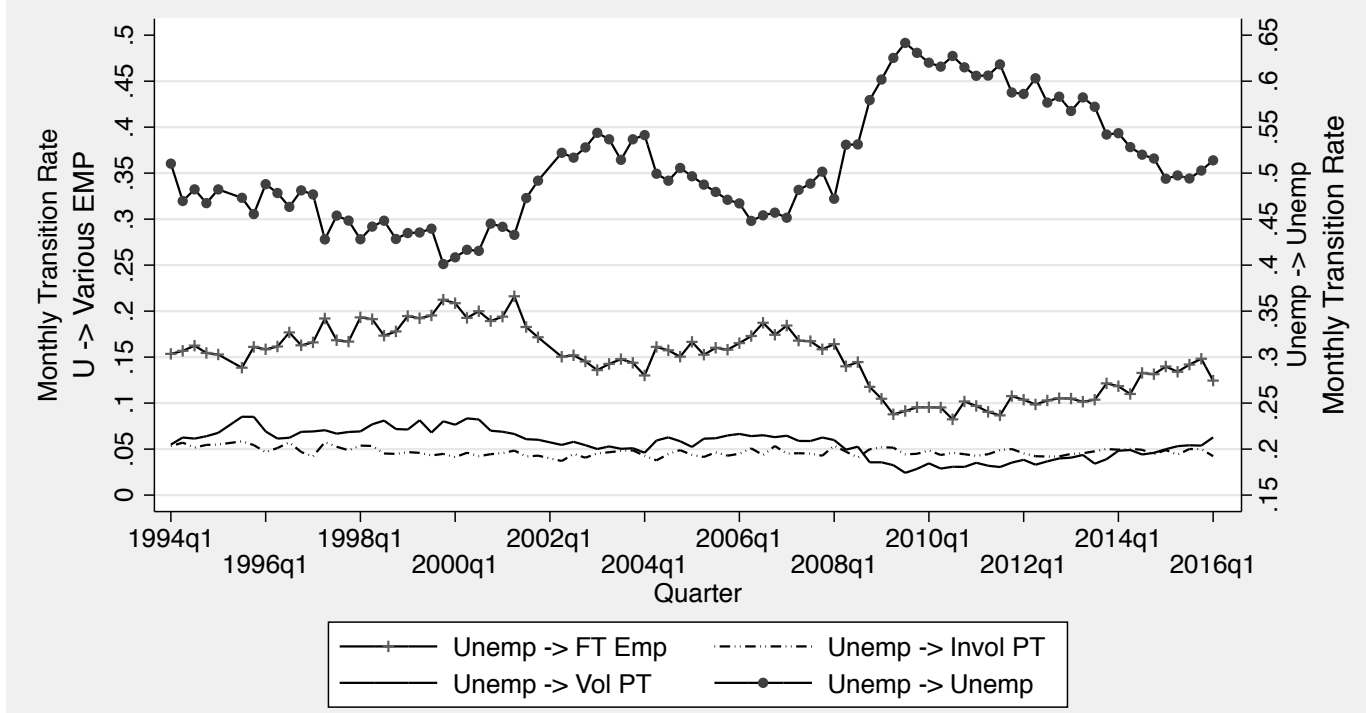

Figure 7: Monthly Flows from Unemployment, Matched CPS

part-time jobs that shows up in the lower transition rates from unemployment to full-time jobs and to voluntary part-time employment.

I turn now to analyses of the experience of displaced workers in order to understand more about the incidence and consequences of job loss in the Great Recession and the slow recovery. I start with a brief description of the Displaced Workers Survey followed by an analysis of job loss rates. I then present an analysis of the employment and earnings consequences of job loss, focusing particularly on the extent to which full-time job losers are reemployed, are reemployed part-time, and the magnitude and sources of earnings losses of job losers.

\section{The Displaced Workers Survey}

I analyze data on 1,203,109 individuals between the ages of twenty and sixty-four from the DWS conducted as part of the January or February CPS in even years from 1984 through 2014. The survey is meant to capture worker terminations as the result of business decisions of the employer (e.g., a plant closing, a layoff, the abolition of a job) unrelated to the performance or choices of the particular employee. As such, it is not meant to capture voluntary job changes (quits) or termination "for cause." While the precise question asked varied somewhat over time, in January 2010 respondents were asked:

"During the last 3 calendar years, that is, January 2007 through December 2009, 
did (name/you) lose a job or leave one because: (your/his/her) plant or company closed or moved, (your/his/her) position or shift was abolished, insufficient work or another similar reason?"

The recall window was five years in the 1984-1992 DWS, and it changed to three years in $1994 .^{7}$

To investigate the consequences of job loss, I use a set of followup questions in the DWS asked of workers who report having lost a job. Unfortunately, since 1994, the follow-up questions were asked only of job losers whose reported reason for the job loss was one of three reasons: slack work, plant closing, or position/shift abolished. I term these the "big three" reasons. Workers who lost jobs due to the ending of a temporary job, the ending of a self-employment situation, or "other" reasons were not asked the follow-up questions. To maintain comparability across years my analysis of post-job-loss experience, regardless of year, uses only workers who lost jobs for one of the "big three" reasons. Additionally, in order to have a consistent sample over time, I do not use information on the post job-loss experience of job losers in the 1984-1992 DWS whose reported job loss was more than three years prior to the interview date.

There are some important issues of definition implicit in the design of this question that are not always recognized in analyses using the DWS. Job loss as measured in these data almost certainly does not represent all job loss about which we ought to be concerned. Specifically, the distinction between quits and layoffs is not always clear. Firms may wish to reduce employment without laying off workers, and they might accomplish this by reducing or failing to raise wages. ${ }^{8}$ This can encourage workers (perhaps those having better alternatives) to quit. Other workers (perhaps those having worse alternatives) might be willing to continue to work at reduced wages. To the extent that these are important phenomena, the sample of individuals observed to be displaced by the definition used in the DWS is a potentially non-random sub-sample of all displaced workers. The consequences of this are difficult to measure, but it is worth noting that the ability of employers to offer at least nominal wage decreases to their workers can be quite limited (Bewley, 1999), a factor that may be

\footnotetext{
7 There are important issues of measurement and interpretation that arise when comparing job loss rates calculated using the DWS over time, including changes in wording of the key questions as well as the change in 1994 in the recall period from five years to three years. See Farber (1997) and Farber (2004) for detailed discussions of these issues and the procedures I use to reweight the data to yield adjusted job loss rates that are comparable over time.

8 This is consistent with work by Jacobsen, LaLonde, and Sullivan (1993) who find that displaced workers suffer earnings declines even before they are displaced.
} 


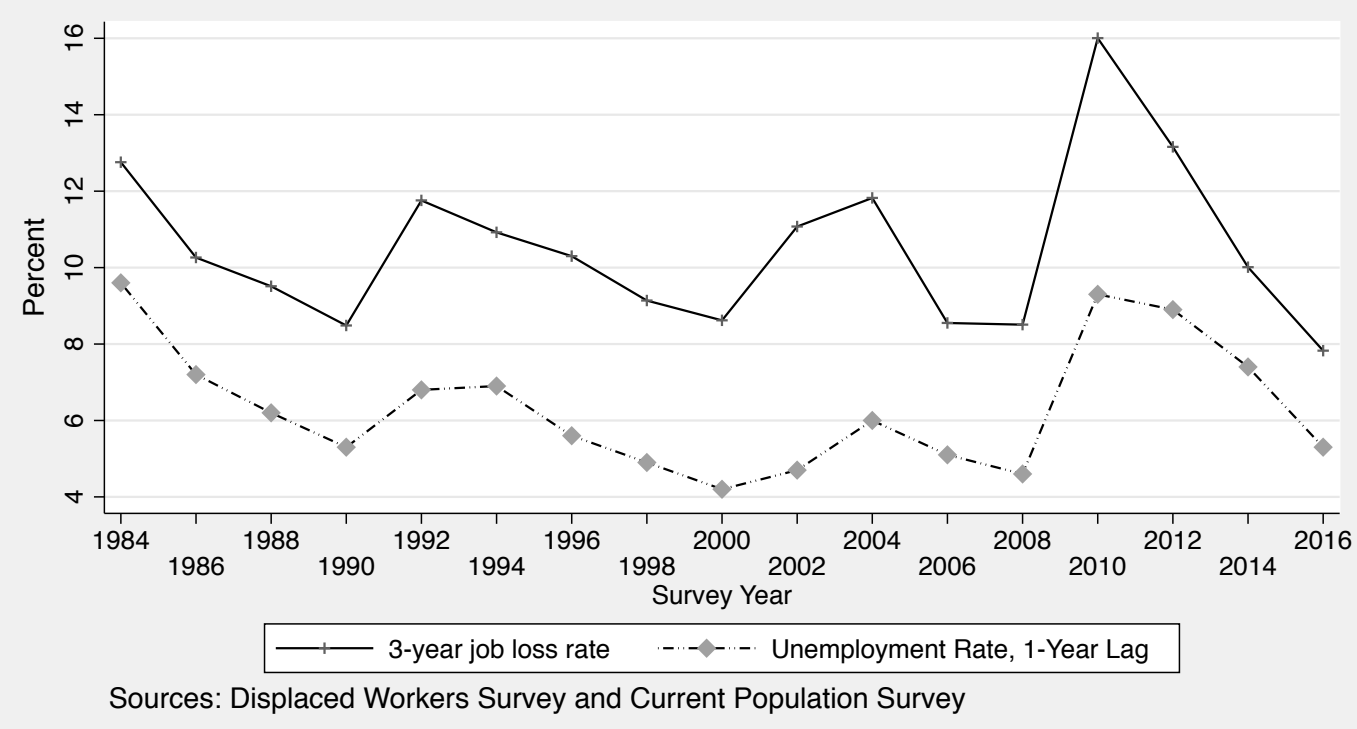

Figure 8: Unemployment and Job Loss Rates, by Survey Year

particularly important in the relatively low inflation environment of the last 20 years.

\section{The Rate of Job Loss}

I begin my analysis of the Displaced Workers Survey with a presentation of basic facts on the rate of job loss. Figure 8 contains plots of adjusted three-year job loss rates computed from each of the 16 DWSs from 1984-2014 along with the civilian unemployment rate for the year preceding each survey. ${ }^{9}$ The cyclical behavior of job loss is apparent, with job-loss rates clearly positively correlated with the unemployment rate $(\rho=0.79) .{ }^{10}$ Both unemployment and job-loss rates were very high in the two most serious recessionary periods (1981-83 and 2007-09, the 1984 and 2010 survey years respectively). While the unemployment rates were comparable in 1983 and 2009 (9.6 percent vs. 9.3 percent), the job loss rate was much higher in the 2007-2009 period than in the 1981-83 period (16.0 percent vs. 12.8 percent). Additionally, the job loss rate fell much more quickly after the 2010 DWS than did the

\footnotetext{
${ }^{9}$ All counts in the figures I present are weighted using the CPS sampling weights.

10 Another possibility would be to use the average unemployment rate for the three years preceding each survey. However, reported rates of job loss are always higher in the year immediately preceding the survey relative to the rates of job loss two and three years preceding the survey. This may be the result of recall bias noted by Topel (1990). Empirically, the correlation of the rate of job loss with the unemployment rate in the year preceding the survey $(\rho=0.79)$ is much higher than the correlation of the rate of job loss with the average unemployment rate in the three years preceding the survey $(\rho=0.45)$.
} 
unemployment rate.

While not presented here, I analyzed variation in job loss rates by important demographic characteristics including education, age, and tenure on the lost job. ${ }^{11}$ Not surprisingly, job loss rates are substantially higher for less educated workers than for more educated workers, but job loss rates for all educational categories show a strong counter-cyclical pattern. Job loss rates are highest for the youngest workers (20-29) and generally show the standard cyclical pattern. There has been some convergence over time in rates of job loss by age, with the rates for older workers increasing relative to those for younger workers. As expected, the job loss rate is monotonically decreasing with tenure in every time period. The job loss rate is far higher and more cyclically sensitive for workers in the first year of their job than for workers in any other tenure category. ${ }^{12}$

\subsection{Full/Part-Time Status and Job Loss}

Figure 9 contains plots of the job loss rates for full- and part-time workers calculated from the basic CPS and DWS from 1996-2014. The calculation is indirect and relies on Bayes rule since the full/part-time status of non-job-losers during the at-risk period is not observed directly in the data. The DWS contains information on full/part-time status on the old (lost) job for job losers, but the full/part-time status of individuals who did not report a job loss during the recall period (the 3 calendar years prior to the DWS) is not observed. Use of Bayes rule yields

$$
P(\text { Loss } \mid F T)=\frac{P(F T \mid \text { Loss }) \cdot P(\text { Loss })}{P(F T)}
$$

and

$$
P(\text { Loss } \mid P T)=\frac{P(P T \mid \text { Loss }) \cdot P(\text { Loss })}{P(P T)} .
$$

All three elements of the right-hand side of these relationships are observable in the basic CPS or the DWS for the appropriate years. ${ }^{13}$

\footnotetext{
${ }^{11}$ See Farber (2015) for more details on this analysis through the 2014 DWS, including a description of how job loss rates by job tenure category were calculated.

12 This is due to at least three factors. First, these are the workers most vulnerable to layoff in a demand downturn. Second, the first year of the job is a period of learning about match quality, and low quality matches are likely to end early (Jovanovic, 1979). Third, there is surely heterogeneity across workers in their underlying turnover rates resulting is very high turnover rates early in jobs among high mobility workers (Farber, 1999). And some of this will come in the form of job loss rather than quits.

13 The probability of full-time and part-time employment conditional on job loss and the overall job loss rate are computed directly from the DWS for each year. The overall probabilities of full-time and part-
} 


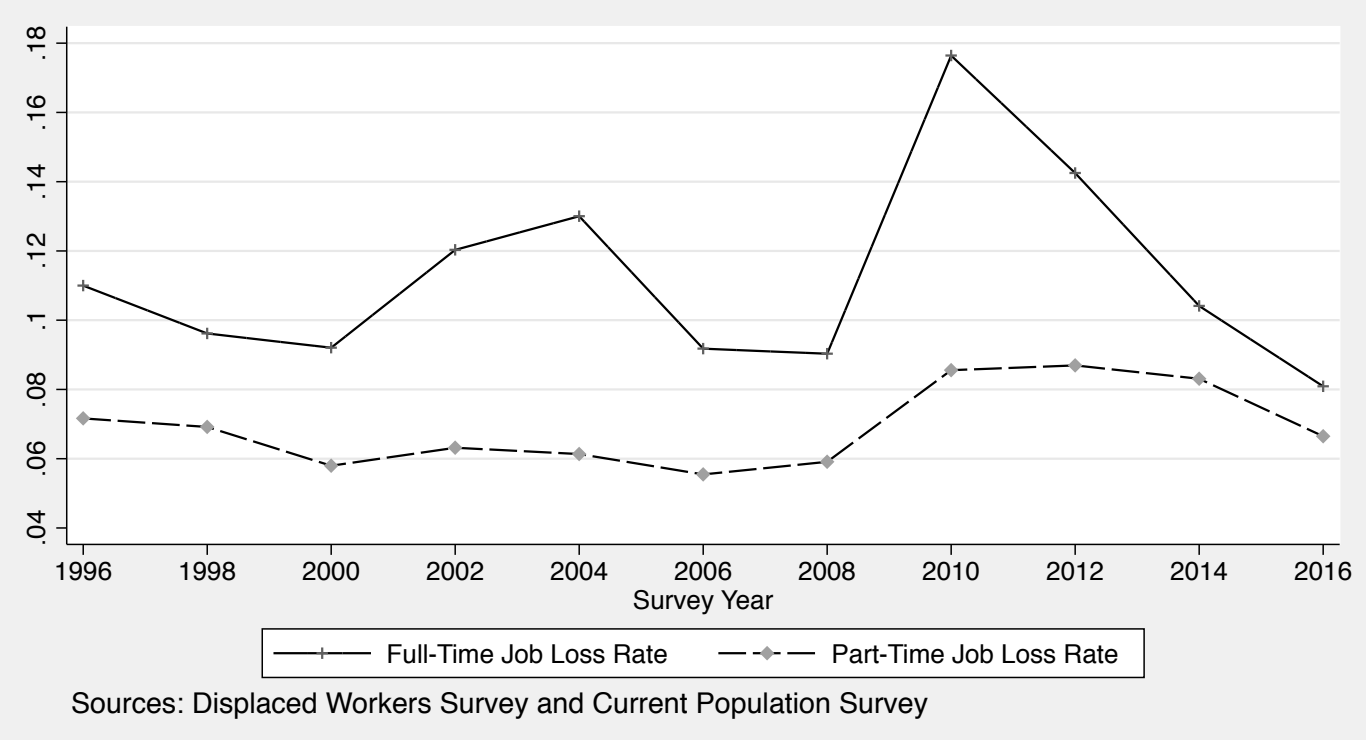

Figure 9: Job Loss Rates, by Full/Part-time Status

It is clear from figure 9 that the rate of job loss for full-time workers is higher than rate of job loss for part-time workers in all years. There is more cyclical variation in the full-time job loss rate, with a sharp spike in the Great Recession and smaller spike in the 2002 recession. Interestingly, the job loss rate for part-time workers increased in the Great Recession and did not decline in the recovery until the 2013-2015 period. There is no information in the DWS on whether workers who were part-time on the lost job were voluntary or involuntary part-time workers.

Most employment is full-time. Tabulation of the CPS since 1994 shows that the annual full-time share of total employment averaged 82.3 percent between 1994 and 2015 (ranging from 80.2 percent to 83.7 percent measured annually). This fact together with the fact that the job-loss rate, shown in figure 9 , is higher for full-time workers than for part-time workers suggests that a very large share of total job loss is from full-time jobs. Simple analysis based on the observed FT/PT shares and the conditional job loss rates calculated using equations 1 and 2 shows that 88 percent of all job loss observed in the DWS since 1996 is from full-time jobs. The full-time share of total job loss is counter-cyclical, with the highest levels reached

time employment are calculated from the basic CPS for the recall period associated with each DWS. For example, the probability of part-time employment for 2014 is the average part-time share of employment for the three-year period 2011-2013. I do not calculate this share for 1994 since there are no comparable data on part-time rates prior to 1994 (Polivka and Miller, 1998). I calculate the part-time rate for 1996 as the average of the 1994 and 1995 values since I cannot use 1993. 
in DWSs covering recession years (2004 and 2010).

There are important differences between full-time and part-time job losers in their postjob-loss experience. In particular, as I show below, part-time job losers are more likely than full-time job losers to exit the labor force and are less likely than full-time job losers to be unemployed. While I can't observe whether part-time job losers were voluntary or involuntary part-time, over three-quarters of overall part-time employment in the period studied is voluntary, suggesting lower attachment to the labor force. It is reasonable to conclude that full-time workers (and job losers) have a stronger attachment to the labor force than part-time workers (and job losers). On this basis, most of my analysis of the consequences of job loss will focus on the experience of the 88 percent of job losers who lost full-time jobs.

\section{Post-Displacement Employment Experience}

The first-order problem faced by job losers is finding another job, and success in doing so is an important factor mitigating earnings losses. I start with an examination of how the survey-date employment rate of job losers has varied over time, both overall and by FT-PT status on the lost job. I follow this with an analysis of the time until re-employment for those job losers who did find a new job, and I conclude this section with an analysis of the survey-date full- and part-time status of reemployed job losers.

\subsection{Survey Date Employment Status of Job Losers}

Figure 10 contains plots of the fraction employed for job losers in each of the DWSs, both overall and by FT-PT status on the lost job. It is clear from this figure that the postdisplacement employment rate is pro-cyclical, with relatively low employment rates in surveys covering the slack labor markets 1984, 1992, 2002, and 2010. The most striking feature of this plot is that the post-displacement employment rate is substantially lower, at less than 50 percent for all job losers taken together and for full-time job losers alone, in the 2010 survey (covering job loss in the 2007-2009 period of the Great Recession) than in any earlier period. And, while the post-displacement employment rate of job losers increased subsequently, the employment rate has not reached the level in earlier periods with strong labor markets. Prior to the Great Recession, part-time job losers had generally lower post-job-loss employment rates than full-time job losers, likely reflecting lower labor force attachment by part-time 


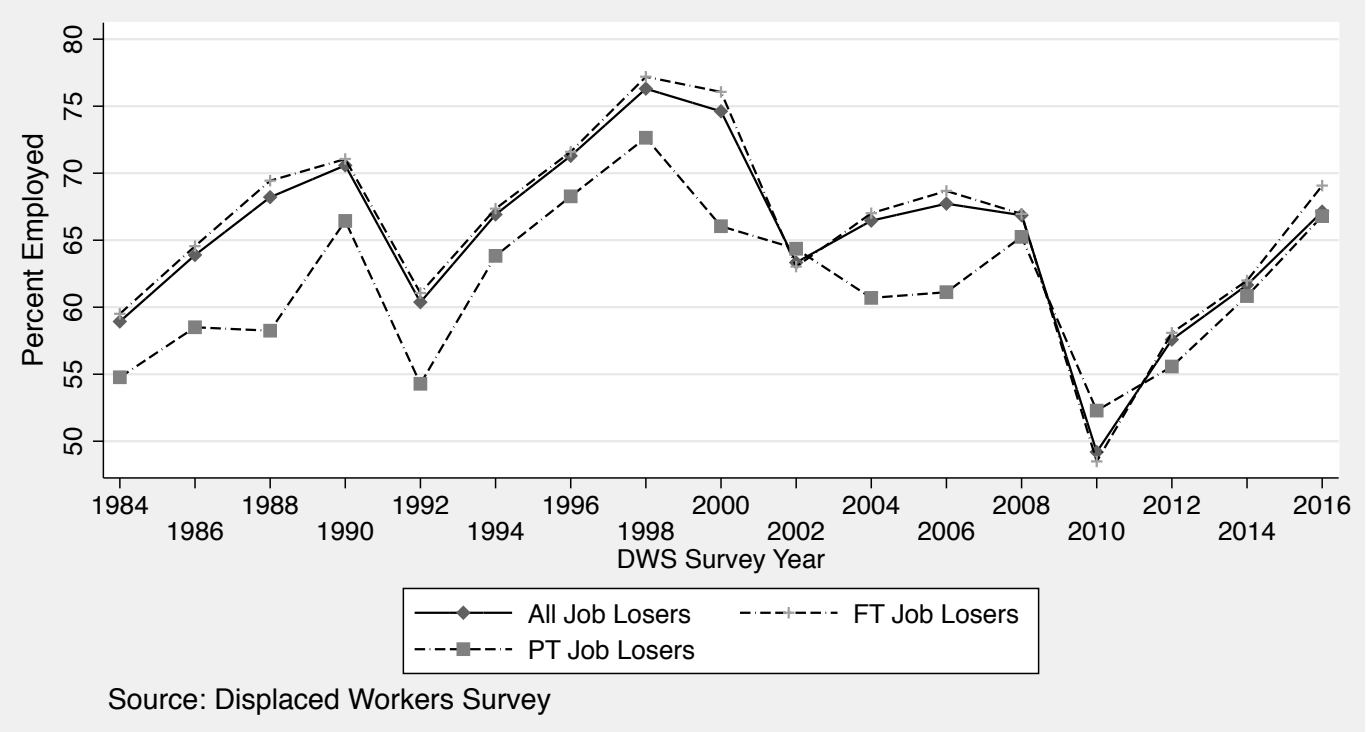

Figure 10: Survey Date Employment Status of Job Losers, by FT/PT Job Loss

workers. ${ }^{14}$ Since 2008, there is no difference in the post-displacement employment rates of full-time and part-time job losers.

In order to investigate differences in post-displacement labor force status across workers with different demographic characteristics, I estimate a linear probability model of postjob-loss employment that accounts for differences in sex, race, age (5 categories), education (4 categories), tenure on the lost job ( 5 categories), the number of years between the job loss and the survey date (3 categories), FT/PT status on the lost job, and survey year (16 categories). While changes in demographic characteristics could account for some of the time series patterns shown in figure 10, this turns out not to be the case. The regression adjusted yearly means are virtually identical to those shown for all job losers in figure $10(\rho=0.99)$. This implies that any changes in the characteristics of job losers over time are unrelated to the time-series movements in post-displacement employment probabilities.

The linear probability model shows substantial differences in post-displacement employment probabilities for workers of different characteristics, and I examine these directly. The first column of table 1 contains estimates of a linear probability model of post-job-loss employment at the DWS survey date using date from the 1994-2016 DWS. These estimates

\footnotetext{
14 An analysis of survey-date unemployment rates and rates of labor force non-participation is consistent with this view. Part-time job losers had lower survey-date unemployment rates and higher survey-date non-participation rates than did full-time job losers. See Farber (2015) for details.
} 
Table 1: Analysis of Post-Job-Loss Employment Outcomes: Linear Probability Models

\begin{tabular}{|c|c|c|c|c|c|}
\hline Variable & $\begin{array}{c}\quad(1) \\
\text { Employed } \\
\text { At Survey }\end{array}$ & $\begin{array}{c}(2) \\
\text { Weeks to } \\
\text { Find Job }\end{array}$ & $\begin{array}{l}(3) \\
\text { FT at } \\
\text { Survey }\end{array}$ & $\begin{array}{c}(4) \\
\text { IVPT at } \\
\text { Survey }\end{array}$ & $\begin{array}{c}(5) \\
\text { VPT at } \\
\text { Survey }\end{array}$ \\
\hline Constant & $\begin{array}{c}0.4801 \\
(0.0098)\end{array}$ & $\begin{array}{c}5.9128 \\
(0.4747)\end{array}$ & $\begin{array}{c}0.7742 \\
(0.0129)\end{array}$ & $\begin{array}{c}0.1428 \\
(0.0104)\end{array}$ & $\begin{array}{c}0.0830 \\
(0.0096)\end{array}$ \\
\hline Age 25-34 & $\begin{array}{c}0.0148 \\
(0.0071)\end{array}$ & $\begin{array}{c}0.5146 \\
(0.3142)\end{array}$ & $\begin{array}{c}0.0623 \\
(0.0105)\end{array}$ & $\begin{array}{l}-0.0213 \\
(0.0083)\end{array}$ & $\begin{array}{l}-0.0410 \\
(0.0081)\end{array}$ \\
\hline Age 35-44 & $\begin{array}{c}0.0005 \\
(0.0074)\end{array}$ & $\begin{array}{c}1.6530 \\
(0.3375)\end{array}$ & $\begin{array}{c}0.0745 \\
(0.0105)\end{array}$ & $\begin{array}{l}-0.0221 \\
(0.0084)\end{array}$ & $\begin{array}{l}-0.0524 \\
(0.0080)\end{array}$ \\
\hline Age $45-54$ & $\begin{array}{l}-0.0323 \\
(0.0078)\end{array}$ & $\begin{array}{c}2.9324 \\
(0.3690)\end{array}$ & $\begin{array}{c}0.0669 \\
(0.0108)\end{array}$ & $\begin{array}{l}-0.0141 \\
(0.0086)\end{array}$ & $\begin{array}{l}-0.0528 \\
(0.0083)\end{array}$ \\
\hline Age 55-64 & $\begin{array}{l}-0.1518 \\
(0.0089)\end{array}$ & $\begin{array}{c}4.2512 \\
(0.4649)\end{array}$ & $\begin{array}{c}0.0043 \\
(0.0125)\end{array}$ & $\begin{array}{l}-0.0084 \\
(0.0097)\end{array}$ & $\begin{array}{c}0.0041 \\
(0.0099)\end{array}$ \\
\hline $\mathrm{ED}<12$ & $\begin{array}{l}-0.0887 \\
(0.0067)\end{array}$ & $\begin{array}{c}0.2887 \\
(0.3705)\end{array}$ & $\begin{array}{l}-0.0588 \\
(0.0107)\end{array}$ & $\begin{array}{c}0.0704 \\
(0.0096)\end{array}$ & $\begin{array}{l}-0.0116 \\
(0.0065)\end{array}$ \\
\hline ED 13-15 & $\begin{array}{c}0.0582 \\
(0.0050)\end{array}$ & $\begin{array}{l}-0.4378 \\
(0.2496)\end{array}$ & $\begin{array}{c}0.0128 \\
(0.0062)\end{array}$ & $\begin{array}{l}-0.0299 \\
(0.0049)\end{array}$ & $\begin{array}{c}0.0171 \\
(0.0046)\end{array}$ \\
\hline $\mathrm{ED} \geq 16$ & $\begin{array}{c}0.1265 \\
(0.0053)\end{array}$ & $\begin{array}{l}-0.6973 \\
(0.2693)\end{array}$ & $\begin{array}{c}0.0529 \\
(0.0062)\end{array}$ & $\begin{array}{l}-0.0492 \\
(0.0049)\end{array}$ & $\begin{array}{l}-0.0037 \\
(0.0045)\end{array}$ \\
\hline Female & $\begin{array}{l}-0.0575 \\
(0.0041)\end{array}$ & $\begin{array}{c}1.6230 \\
(0.2111)\end{array}$ & $\begin{array}{l}-0.0897 \\
(0.0052)\end{array}$ & $\begin{array}{c}0.0147 \\
(0.0040)\end{array}$ & $\begin{array}{c}0.0750 \\
(0.0039)\end{array}$ \\
\hline Nonwhite & $\begin{array}{l}-0.1061 \\
(0.0058)\end{array}$ & $\begin{array}{c}1.8712 \\
(0.3200)\end{array}$ & $\begin{array}{c}0.0069 \\
(0.0073)\end{array}$ & $\begin{array}{c}0.0173 \\
(0.0061)\end{array}$ & $\begin{array}{l}-0.0242 \\
(0.0050)\end{array}$ \\
\hline Tenure 1-3 Yr & $\begin{array}{c}0.0343 \\
(0.0050)\end{array}$ & $\begin{array}{c}0.5633 \\
(0.2328)\end{array}$ & $\begin{array}{c}0.0166 \\
(0.0063)\end{array}$ & $\begin{array}{l}-0.0166 \\
(0.0051)\end{array}$ & $\begin{array}{c}0.0000 \\
(0.0046)\end{array}$ \\
\hline Tenure $3-120 \mathrm{Yr}$ & $\begin{array}{c}0.0378 \\
(0.0060)\end{array}$ & $\begin{array}{c}1.7993 \\
(0.3081)\end{array}$ & $\begin{array}{c}0.0341 \\
(0.0072)\end{array}$ & $\begin{array}{l}-0.0324 \\
(0.0056)\end{array}$ & $\begin{array}{l}-0.0016 \\
(0.0053)\end{array}$ \\
\hline Tenure $11-20 \mathrm{Yr}$ & $\begin{array}{c}0.0234 \\
(0.0078)\end{array}$ & $\begin{array}{c}2.4545 \\
(0.4352)\end{array}$ & $\begin{array}{c}0.0368 \\
(0.0091)\end{array}$ & $\begin{array}{l}-0.0349 \\
(0.0070)\end{array}$ & $\begin{array}{l}-0.0019 \\
(0.0066)\end{array}$ \\
\hline Tenure $>20 \mathrm{Yr}$ & $\begin{array}{l}-0.0530 \\
(0.0094)\end{array}$ & $\begin{array}{c}3.3818 \\
(0.6101)\end{array}$ & $\begin{array}{c}0.0243 \\
(0.0110)\end{array}$ & $\begin{array}{l}-0.0307 \\
(0.0088)\end{array}$ & $\begin{array}{c}0.0065 \\
(0.0077)\end{array}$ \\
\hline 2 Yr Since Loss & $\begin{array}{c}0.1925 \\
(0.0047)\end{array}$ & $\begin{array}{c}6.2309 \\
(0.2046)\end{array}$ & $\begin{array}{c}0.0311 \\
(0.0059)\end{array}$ & $\begin{array}{l}-0.0209 \\
(0.0047)\end{array}$ & $\begin{array}{c}-0.0101 \\
(0.0043)\end{array}$ \\
\hline 3 Yr Since Loss & $\begin{array}{c}0.2364 \\
(0.0048)\end{array}$ & $\begin{array}{c}8.9864 \\
(0.2539)\end{array}$ & $\begin{array}{c}0.0320 \\
(0.0061)\end{array}$ & $\begin{array}{l}-0.0268 \\
(0.0048)\end{array}$ & $\begin{array}{l}-0.0052 \\
(0.0045)\end{array}$ \\
\hline PT Lost Job & $\begin{array}{l}-0.0105 \\
(0.0066)\end{array}$ & $\begin{array}{l}-1.8959 \\
(0.3187)\end{array}$ & $\begin{array}{l}-0.2877 \\
(0.0101)\end{array}$ & $\begin{array}{c}0.0570 \\
(0.0077)\end{array}$ & $\begin{array}{c}0.2307 \\
(0.0091)\end{array}$ \\
\hline Sample & All & Employed & Employed & Employed & Employed \\
\hline Years & $1984-2016$ & $1988-2016$ & $1994-2016$ & 1994-2016 & $1994-2016$ \\
\hline$N$ & 68001 & 36809 & 30460 & 30460 & 30460 \\
\hline R-Squared & 0.118 & 0.096 & 0.101 & 0.036 & 0.102 \\
\hline
\end{tabular}

Note: Data from the 1984-2016 DWS. Weighted by CPS sampling weights. The base category is white males in first 1984 aged 20-24 with 12 years of education and less than one year of tenure and who lost a job in the calendar year immediately prior to the survey date. There are no data for 1994 in column 2. All models include a complete set of survey year fixed effects. Robust standard errors are in parentheses. 
show that more educated workers are substantially more likely to be employed subsequent to job loss, with a college - high school gap in the employment probability of 12.5 percentage points. Older workers are less likely to be employed, with workers aged 55-64 about 16 percentage points less likely than workers aged 35-44 to be employed. Females are about 6 percentage points less likely than men to be employed, while nonwhites are about 10 percentage points less likely than whites to be employed. Workers who lost jobs with 1-20 years tenure are 3 to 4 percentage points more likely than workers who lost short-term (less than one year) job to be employed, while workers who lost jobs with more than 20 years tenure are about 8 percentage points less likely than workers who lost jobs with 1-20 years tenure to be employed. Finally, elapsed time since job loss has an important effect on the likelihood of employment at the survey date. Workers who lost jobs more than one year prior to the DWS survey date are about 20 percentage points more likely to be employed then are workers who lost a job in the year immediately prior to the survey date. There is only a small difference in the average post-loss employment rate by FT/PT status on the lost job.

\subsection{The Length of Time to Find and Job}

The DWS is not well designed to study the length of time it takes job losers to find another job. The core question in the DWS, included in the survey from 1988 on, is "After that job [referring to the lost job] ended, how many weeks went by before you started working again at another job?" However, this question is asked of all job losers only from 1988-1992. The data on this question are miscoded (largely missing) in 1994, and from 1996 on the question is asked only of job losers who found another job. Therefore, consistent data are available from the 1988-92 and 1996-2014 DWSs, and, even then, only for those job losers who found a new job.

I proceed with an analysis of average weeks to find a job conditional on finding a job. This is plotted in figure 11. The time to find a job, after declining from the mid 1980s through 2000, increased dramatically from 2005-07 to 2009-11. The job-finding time has since fallen, but it remains high relative to the pre-Great-Recession period. The multivariate analysis of job-finding time, contained in column 2 of table 1 shows small differences by education (a college high-school gap of less than one week) but large gaps by age. Reemployed job losers who are 45-64 take 3-4 weeks longer to find jobs than the youngest job losers. ${ }^{15}$ Similarly,

\footnotetext{
15 This is consistent with evidence from recent audit studies of the likelihood of callback to job applications that find lower callback rates for older workers. See Farber, Silverman, and von Wachter (2016), Lahey (2008) and Neumark, Burn, and Button (2015).
} 


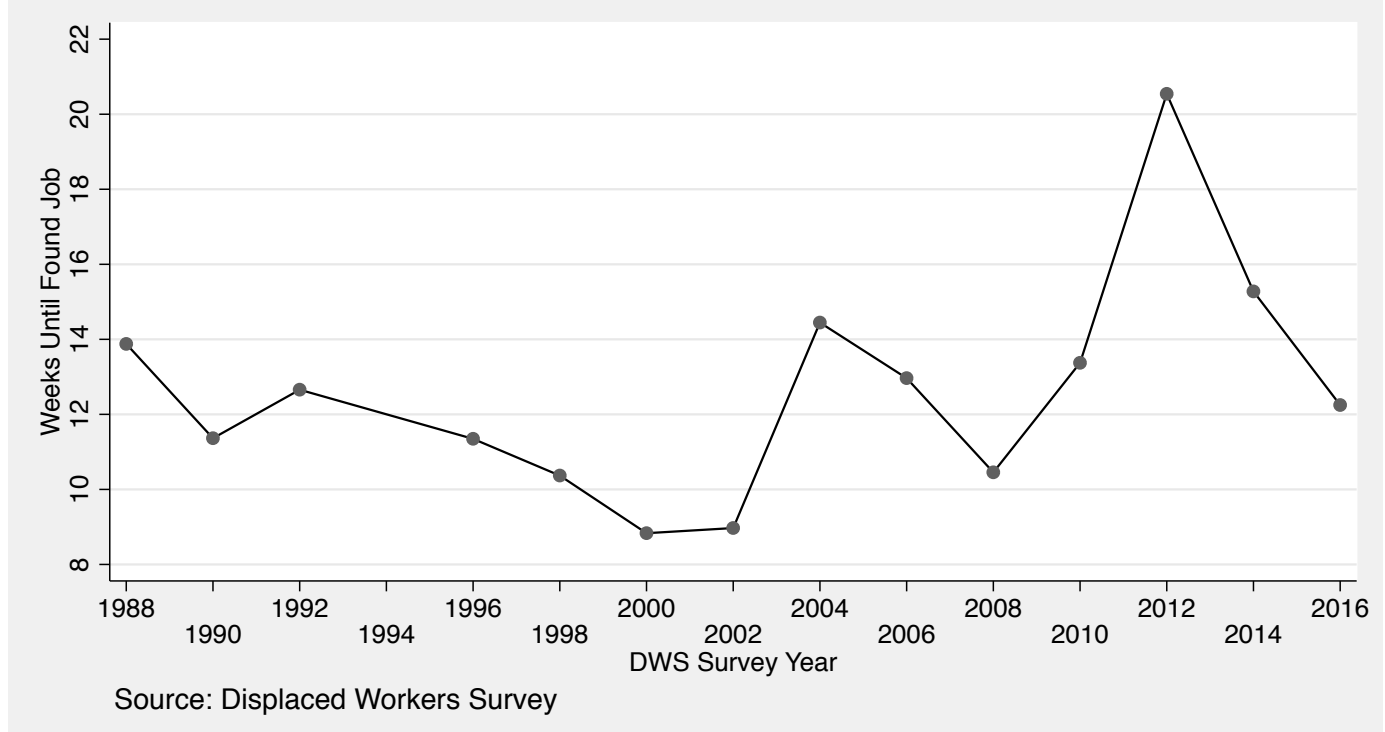

Figure 11: Average Weeks to Find a Job Conditional on Ever Employed, by Year

reemployed high-tenure job losers take longer to find a new job, even after accounting for age. The relationship is monotone. Relative to workers who lost very short jobs, those who lost a job with 3-10 years tenure take 2 weeks longer to find a job while those with more than 20 year tenure on the lost job take 4 weeks longer. Reemployed females and nonwhites take one to two weeks longer to find jobs.

Interestingly, those who lost their job more than one year ago take substantially more time to find their new job (6 to 8 weeks more). It may be that those who report losing a job in the year immediately prior to the survey have not had much time to search (and so mechanically cannot report long durations). This is also consistent with the pattern of lower reemployment probabilities for those who lost jobs in the year prior to the survey (column 1 of table 1). Another explanation may be related to recall bias (Topel, 1990). If, with the passage of time, job losses with more serious consequences are more likely to be recalled, then the job losses reported having happened more than one year before the survey date would more likely be those with longer post-job-loss spells of non-employment.

\subsection{Hours of Re-employed Job Losers}

Despite the finding that there is little difference in the overall employment rate by $\mathrm{FT} / \mathrm{PT}$ status on the lost job (column 1 of table 1), there are clearly differences in this dimension in post-job loss hours. I examine this by looking at FT/PT status on the new job for re- 
employed job losers. Panel A of figure 12 shows the FT/PT status on the new job for all job losers. ${ }^{16}$ The post-job-loss full-time employment share (left axis scale) decreased in the 2001 recession and it did not recover before declining substantially further in the Great Recession with modest recovery since. These changes are entirely accounted for by offsetting increases in the involuntary part-time share (right axis scale). The voluntary part-time rate (right axis scale) does not show substantial movement. Panel B of figure 12 repeats this analysis for full-time job losers, and the same general pattern is found with the exception of more recovery following the Great Recession (increased FT share, decreased IV PT share). A very different pattern is found for part-time job losers (panel $\mathrm{C}$ of the figure) relative to full-time job losers (panel B). ${ }^{17}$ The post-job-loss full-time employment share is much lower for part-time job losers relative to full-time job losers (45-55 percent vs. $80-90$ percent). The voluntary part-time employment share is much higher for part-time job losers relative to full-time job losers (30-40 percent vs. 5-8 percent), reflecting labor supply differences. Interestingly, the involuntary part-time share for part-time job losers was close to zero from 1996 through 2002 but increased slowly in 2004 and 2006 before increasing sharply in the Great Recession (from about 14 percent in 2008 to 25 percent in 2010). It remains relatively high at 18.3 percent in 2016.

There are systematic differences by demographic characteristics in hours of work among re-employed job losers. In order to investigate this, I present estimates of linear probability models of FT, IV-PT, and V-PT employment for re-employed job losers in columns 4-6 respectively, of table 1 . Workers with more education are more likely to be working fulltime and less likely to be working involuntary part-time. The relationships with age are non-monotonic. The youngest (20-24) and oldest (55-64) job losers are less likely to be working full-time and more likely to be voluntary part-time than prime-age job losers (2554). Workers who lost a job on which they had more tenure are more likely to be full-time and less likely to be involuntary part-time. More time since job loss increases the probability of full-time employment and decreases the probability of involuntary part-time employment. This suggests that job losers take part-time jobs but continue to search for full-time jobs.

Female job losers are less likely to be full-time and more likely to be voluntary part-time.

\footnotetext{
16 The analysis of the FT/PT status of job losers is limited to the 1994-2014 period due to the difficulty in defining comparable measures of voluntary and involuntary part-time employment before and after the 1994 CPS redesign.

17 Recall that the DWS does not collect information for part-time job losers on whether the lost part-time job was voluntary or involuntary part-time.
} 
(A) All Employed Job Losers

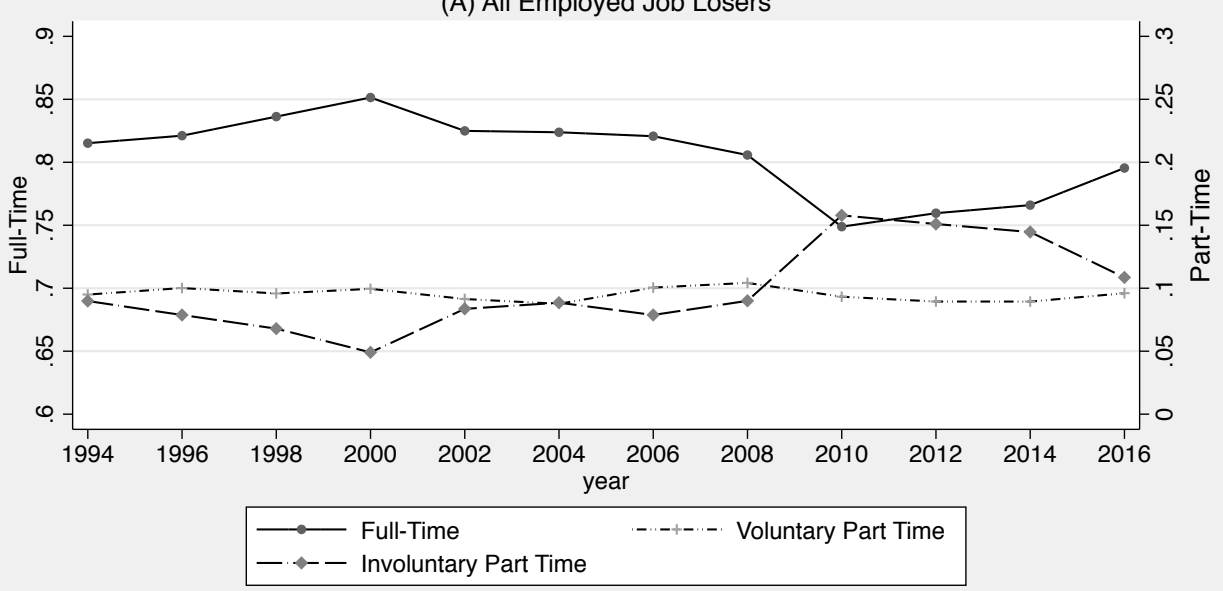

Source: Displaced Workers Survey

\section{(B) Employed Full-Time Job Losers}

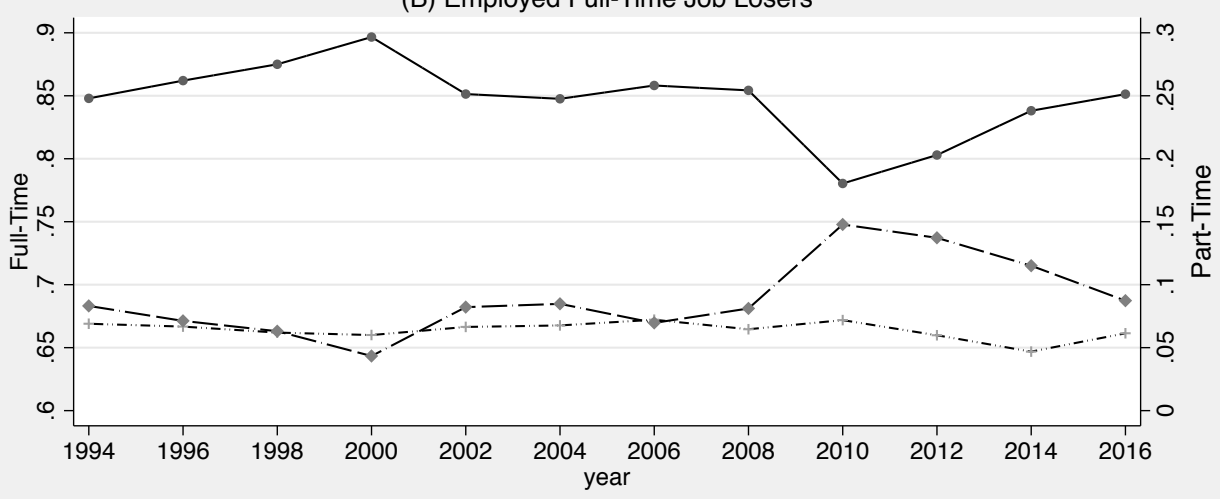

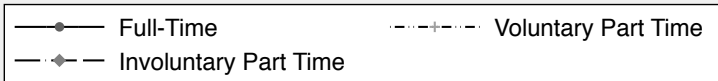

Source: Displaced Workers Survey

(C) Employed Part-Time Job Losers

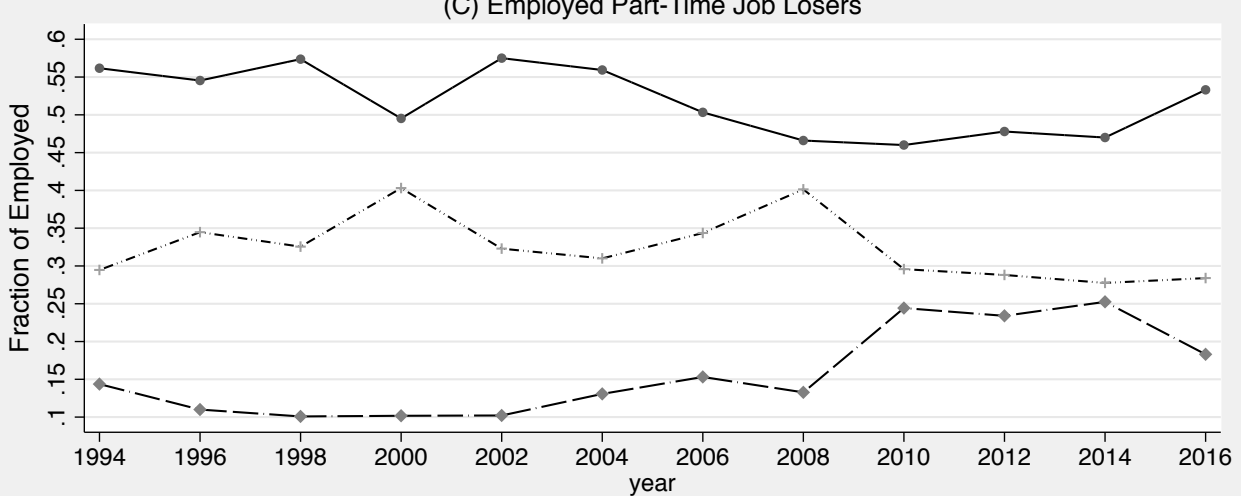

\begin{tabular}{lll}
\hline —- Full-Time & $\cdots+\cdots-\cdots$ & Voluntary Part Time \\
- Involuntary Part Time & \\
\hline
\end{tabular}

Source: Displaced Workers Survey

Figure 12: Full-Time / Part-Time Status of Employed Job Losers 
While this likely reflects labor supply choices, note that I am controlling for PT status on the lost job, which has a dramatic effect on FT/PT status on the post-loss job. Reemployed part-time job losers are 29 percentage points less likely to be full-time job and 23 percentage more likely to be voluntary part-time. This largely reflects differences in labor supply.

The overall pattern that I have described in this section highlight just how serious the effect of the Great Recession was on the ability of job losers to find employment, and, particularly, full-time employment. The perhaps surprising general finding is that even by 2015 (the last year covered by the DWS and 6 years after the end of the Great Recession) is that the ability of job losers to find new jobs remains compromised. The full-time employment share remains depressed, and the involuntary part time employment share remains high.

\section{Real Earnings Consequences of Job Loss}

To focus my analysis of real earnings loss, I limit my analysis to losers of full-time jobs (88 percent of all DWS job loss), and I define the change in earnings of a job loser to be the difference between real weekly earnings in the DWS survey week and real weekly earnings on the lost job as reported in the DWS. ${ }^{18}$ This is neither a measure of total lost earnings, which would include earnings foregone during a period of non-employment subsequent to job loss, nor a measure of any long-run reduction in earnings. ${ }^{19}$ However, information in the DWS can be used to measure the change in survey-date weekly earnings, and I can attribute changes in this quantity to three sources:

1. Full-time job losers who find a new full-time job may earn less per week on their new job. This is particularly likely if they lost a job on which they had substantial tenure.

2. Some job losers who find a new job may work fewer hours, perhaps transitioning from full-time to part-time employment. These workers are likely to suffer a substantial decline in earnings due both to lower hours and to a lower wage per hour worked.

3. Some job losers will not be employed at the DWS survey date. While these individuals may receive unemployment insurance benefits, they are not earning, and their earnings loss is 100 percent.

\footnotetext{
18 I deflate reported nominal earnings in the DWS by the CPI for the DWS survey month. I deflate reported nominal earnings on the lost job by the CPI in the year of reported job loss.

19 The DWS is not particularly well suited to study either of these given the lack of precise information on duration of non-employment and long run earnings trajectory.
} 
A descriptive framework for decomposing the proportional change in weekly earnings experienced by full-time job losers into these three channels is as follows. The average proportional change in real weekly earnings is

$$
\begin{aligned}
\Delta & =P_{F} \cdot \frac{W_{F}-W_{0}}{W_{0}}+P_{P} \cdot \frac{W_{P}-W_{0}}{W_{0}}+P_{N} \frac{0-W_{0}}{W_{0}} \\
& =P_{F} \cdot \frac{W_{F}-W_{0}}{W_{0}}+P_{P} \cdot \frac{W_{P}-W_{0}}{W_{0}}-P_{N},
\end{aligned}
$$

where $W_{0}$ is pre-displacement weekly earnings, $W_{F}$ is post-displacement full-time weekly earnings, $W_{P}$ is post-displacement part-time weekly earnings, and $P_{F}, P_{P}$, and $P_{N}$ represent the probabilities of reemployment full-time, reemployment part-time and no reemployment respectively $\left(P_{F}+P_{P}+P_{N}=1\right)$. The first term in equation 3 is the contribution of the change in weekly earnings of the full-time reemployed, the second term is the contribution of the change in weekly earnings of the part-time reemployed, and the third term is the contribution of the change in weekly earnings of those not reemployed.

In order to get an idea of the average magnitudes of the contributions of the elements of this decomposition, the overall average values for full-time job losers for the 1984-2014 period $\operatorname{are}^{20}$

$$
\begin{aligned}
\Delta & =P_{F} \cdot \frac{W_{F}-W_{0}}{W_{0}}+P_{P} \cdot \frac{W_{P}-W_{0}}{W_{0}}-P_{N} \\
& =0.611 \cdot(-0.0120)+0.086 \cdot(-0.416)-0.303 \\
& =-0.0073-0.0359-0.303 \\
& =-0.346 .
\end{aligned}
$$

Earnings for full-time job losers were 34.6 percent lower on average at the subsequent DWS survey date. Fully 87.5 percent of the overall earnings loss is due to the fact that the 30.3 percent of full-time job losers who were not employed at the survey date subsequent to job loss lost 100 percent of their earnings. The 8.6 percent of full-time job losers who found a part-time job suffered a 41.6 percent earnings decline, which accounts for 10.4 percent of total earnings loss. Interestingly, the 61.1 percent of full-time job losers who found a new full-time job, lost only 1.2 percent of their earnings on average, accounting for only 2.1 percent of the total earnings loss. The key message is clear: Virtually all loss in earnings by full-time job losers is the result of lower employment rates and lower hours among those reemployed.

\footnotetext{
${ }^{20}$ In this calculation and what follows, I trim the smallest and largest 1 percent of proportional earnings changes among the reemployed.
} 
Given the high non-employment rates of job losers, it is not surprising that most earnings loss is borne by these workers. But it also overstates the long-run earnings effect of job loss since many of these workers will likely be re-employed at some point. It is useful to redo this decomposition focusing only on the earnings loss of re-employed job losers. This is

$$
\begin{aligned}
\Delta & =\frac{P_{F}}{P_{F}+P_{P}} \cdot \frac{W_{F}-W_{0}}{W_{0}}+\frac{P_{P}}{P_{F}+P_{P}} \cdot \frac{W_{P}-W_{0}}{W_{0}} \\
& =0.877 \cdot(-0.0120)+0.123 \cdot(-0.416) \\
& =-0.0105-0.0512 \\
& =-0.0617 .
\end{aligned}
$$

Earnings for re-employed full-time job losers were 6.2 percent lower on average at the subsequent DWS survey date. Note that most (87.7 percent) of re-employed full-time job losers were in a new full-time job and their earnings declined very little on average, while the earnings of the 12.3 percent of full-time job losers who were re-employed part-time dropped substantially. As a result, about 83 percent of the overall average earnings decline among reemployed job losers is due to the drop in earnings when moving from a full-time job to a part-time jobs (largely an hours effect), with 17 percent due to the small average decline in earnings suffered by workers making a FT-FT transition.

While it is not surprising that the weekly earnings losses suffered by workers making a FT-PT transition are substantial, it is surprising that the average weekly earnings decline suffered by full-time job losers who find another full-time job are very small (about 1.5 percent). ${ }^{21}$ However, there is considerable heterogeneity both across workers and over time in earnings losses for full-time job losers. In order to explore this heterogeneity, I estimate WLS regression models of the proportional earnings change of full-time job losers. These models include DWS survey year fixed effects along with controls for demographic characteristics (education, age, sex, race), tenure on the lost job, time since job loss. Figure 13 contains the estimates of year-specific intercepts (the year fixed effects) which represent the regressionadjusted average earnings changes of full-time job losers in the base group calculated at the median for each control variable (white males, age 35-44 with 12 years of education and

21 I note that my earlier work using the DWS (e.g., Farber (2004), Farber (2013) reports substantially larger earnings declines for workers making a FT-FT transition. It is with some embarrassment that I recognize that the earlier work reports the proportional wage change implied by the average log wage change rather than the average of the individual proportional wage changes themselves. This can be misleading because the individual proportional wage changes are quite variable and are not well approximated by the individual changes in log wages. Importantly, the proportional wage change implied by the average change in log wages is generally smaller (more negative) than the simple average of the proportional wage changes. 




Figure 13: Proportional Change in Real Weekly Earnings for Full-Time Job Losers

1-3 of tenure on the lost job who lost a job in the second calendar year prior to the survey date). ${ }^{22}$

The estimates of the year-specific regression-adjusted average earnings change for the base group using on a sample of all full-time job losers, including those who are not employed at the survey date, are represented by the lower line in figure 13. Because the proportional earnings change of the not-employed is -1 , these average proportional earnings changes are substantially negative in all years (average of yearly changes -21.6 percent) and has substantial cyclical variation, ranging from -38.8 percent in 2010 (the Great Recession) to -5.3 percent in 2000 (a strong labor market). The earnings loss has declined since the Great recession (to 13.7 percent in 2016), and it is only now back to pre-recession levels.

The estimates in the upper solid line of figure 13 are based on the subgroup of reemployed full-time job losers who are employed at the survey date. The earnings changes of this group show much less cyclical volatility, are substantially less negative, and even positive in some years, ranging from -8.5 percent in 1992 (a recession period) to +3.0 percent in 1998 and 2000 (averaging -3 percent and positive in 3 of the 17 DWS survey years, including 2016). The estimates in upper dashed line of the figure are based only on the 87.7 percent of reemployed full-time job losers who are reemployed in a full time job. These estimates refer to workers

\footnotetext{
22 The estimates of coefficients of demographic and other variables included in the model are presented separately in table 2 .
} 
making a FT-FT transition, and the earnings changes of this group are even less negative / more positive in some years (averaging -0.5 percent, ranging from -6.1 percent in 1992 to +5.0 percent in 1998, and positive in 7 of the 17 DWS survey years, including 2014 and 2016).

This analysis reinforces the result from the simple decomposition of weekly earnings changes: Most earnings loss suffered by full-time job losers is from the loss of hours. The lion's share of this comes from non-employment subsequent to job loss (a complete loss of hours) and much of the rest is due to the fact that some full-time job losers are reemployed part-time (a partial loss of hours). Very little of the average weekly earnings loss is due to a reduction in the average weekly earnings of full-time job losers who make a FT-FT transition.

The year-specific average weekly earnings changes refer to full-time job losers who are in the base group. While this group was chosen by selecting the median value of each characteristic (white, male, age 35-44, 12 years of education, 1-3 years of tenure, having a lost a job in the second calendar year prior to the DWS survey date), these averages mask substantial variation, with some groups, in fact, having substantial earnings losses even when reemployed full-time. This is clear on inspection of table 2, which contains the estimates of the coefficients of the worker characteristics associated with the year-specific average changes in figure 13.

The estimates in the first column of table 2 are based on the sample of all full-time job losers, including those who are not employed at the survey date. Education has a substantial effect on the weekly earnings change, with more education implying substantially larger (less negative / more positive) earnings changes. Women and non-whites have smaller (more negative) earnings changes. Older workers and workers with more tenure on the lost job suffer greater earnings losses. Finally, as time passes since job loss, the earnings change is larger (less negative). Much of this is driven the relationship of these characteristics with the likelihood of finding employment. The estimates of survey-date employment probabilities in the first column of table 1 are consistent in showing that females, non-whites, older workers (45-64), and workers who lost their job in the year immediately prior to the survey date have lower employment probabilities. The role of tenure on the lost job is more nuanced, with only workers in the highest tenure category ( $>20$ years) having a lower employment probability.

The estimates in column 2 of table 2 abstract from the employment probability by focusing on the subgroup of full-time job losers who are employed at the survey date. Here 
Table 2: Analysis of Earnings Change of Full-Time Job Losers

\begin{tabular}{|c|c|c|c|c|}
\hline Post Emp Status: & $\begin{array}{l}(1) \\
\text { All }\end{array}$ & $\begin{array}{c}(2) \\
\text { Employed }\end{array}$ & $\begin{array}{c}(3) \\
\text { Employed }\end{array}$ & $\begin{array}{c}(4) \\
\text { Emp FT }\end{array}$ \\
\hline \multirow[t]{2}{*}{$\mathrm{ED}<12$} & -0.0838 & -0.0157 & -0.0022 & -0.0135 \\
\hline & $(0.0095)$ & $(0.0097)$ & $(0.0093)$ & $(0.0101)$ \\
\hline \multirow[t]{2}{*}{ ED $13-15$} & 0.0504 & 0.0047 & 0.0020 & 0.0033 \\
\hline & $(0.0075)$ & $(0.0070)$ & $(0.0066)$ & $(0.0071)$ \\
\hline \multirow[t]{2}{*}{$\mathrm{ED} \geq 16$} & 0.1225 & 0.0374 & 0.0180 & 0.0247 \\
\hline & $(0.0079)$ & $(0.0071)$ & $(0.0068)$ & $(0.0072)$ \\
\hline \multirow[t]{2}{*}{ Female } & -0.0319 & -0.0415 & -0.0005 & -0.0017 \\
\hline & $(0.0060)$ & $(0.0056)$ & $(0.0053)$ & $(0.0057)$ \\
\hline \multirow[t]{2}{*}{ Nonwhite } & -0.1046 & -0.0069 & -0.0058 & -0.0020 \\
\hline & $(0.0086)$ & $(0.0087)$ & $(0.0082)$ & $(0.0088)$ \\
\hline \multirow[t]{2}{*}{ Age $20-24$} & 0.0644 & 0.0656 & 0.0887 & 0.0967 \\
\hline & $(0.0119)$ & $(0.0113)$ & $(0.0107)$ & $(0.0116)$ \\
\hline \multirow[t]{2}{*}{ Age $25-34$} & 0.0476 & 0.0357 & 0.0394 & 0.0445 \\
\hline & $(0.0078)$ & $(0.0072)$ & $(0.0068)$ & $(0.0073)$ \\
\hline \multirow[t]{2}{*}{ Age $45-54$} & -0.0489 & -0.0241 & -0.0202 & -0.0235 \\
\hline & $(0.0084)$ & $(0.0077)$ & $(0.0074)$ & $(0.0078)$ \\
\hline \multirow[t]{2}{*}{ Age 55-64 } & -0.1396 & -0.0749 & -0.0475 & -0.0473 \\
\hline & $(0.0103)$ & $(0.0101)$ & $(0.0094)$ & $(0.0100)$ \\
\hline \multirow[t]{2}{*}{ Tenure $<1$ Yr } & -0.0170 & 0.0203 & 0.0305 & 0.0228 \\
\hline & $(0.0077)$ & $(0.0072)$ & $(0.0069)$ & $(0.0074)$ \\
\hline \multirow[t]{2}{*}{ Tenure $3-10 \mathrm{Yr}$} & -0.0352 & -0.0496 & -0.0528 & -0.0534 \\
\hline & $(0.0079)$ & $(0.0073)$ & $(0.0069)$ & $(0.0073)$ \\
\hline \multirow[t]{2}{*}{ Tenure $11-20 \mathrm{Yr}$} & -0.0734 & -0.1032 & -0.1087 & -0.1096 \\
\hline & $(0.0099)$ & $(0.0091)$ & $(0.0086)$ & $(0.0091)$ \\
\hline \multirow[t]{2}{*}{ Tenure $>20 \mathrm{Yr}$} & -0.1046 & -0.1256 & -0.1284 & -0.1187 \\
\hline & $(0.0142)$ & $(0.0141)$ & $(0.0131)$ & $(0.0144)$ \\
\hline \multirow[t]{2}{*}{1 Yr Since Loss } & -0.2329 & -0.0233 & -0.0131 & -0.0127 \\
\hline & $(0.0070)$ & $(0.0066)$ & $(0.0062)$ & $(0.0067)$ \\
\hline \multirow[t]{2}{*}{3 Yrs Since Loss } & 0.0587 & 0.0041 & 0.0066 & 0.0076 \\
\hline & $(0.0077)$ & $(0.0069)$ & $(0.0066)$ & $(0.0070)$ \\
\hline PT New Job & - & - & $\begin{array}{l}-0.4036 \\
(0.0080)\end{array}$ & - \\
\hline Year FEs & Yes & Yes & Yes & Yes \\
\hline$N$ & 41426 & 28875 & 28875 & 25315 \\
\hline R-Squared & 0.123 & 0.036 & 0.135 & 0.038 \\
\hline
\end{tabular}

Note: Based on data from the 1984-2016 DWS. Weighted by CPS sampling weights. The base category is at the median for each variable and consists of white males aged 35-44 with 12 years of education and 1-3 years of tenure and who lost a job in the second calendar year prior to the survey date. All models include a complete set of survey year fixed effects. These estimated year fixed effects related to the models in columns 1, 2, and 4 are presented in figure 13. Robust standard errors are in parentheses. 
the differences by education, race, and time since job loss are greatly attenuated, again suggesting that substantial variation in earnings loss is driven by variation in the likelihood of finding employment. However, substantial differences in earnings loss by sex, age, and tenure on the lost job remain when considering only reemployed job losers. The estimates in columns 3 and 4 account for part-time employment on the job held at the survey date (column 3 with an explicit control and column 4 by limiting the sample to those making a FT-FT transition). Once FT/PT status on the new job is accounted for, there is no difference in the average earning change by sex. However, substantial differences by age and tenure remain, with older and higher tenure workers suffering larger earnings declines.

The clear messages from figure 13 and table 2 are 1) that most earnings decline of fulltime job losers comes from lack of employment subsequent to job loss and 2) the "average" full-time reemployed job loser does not suffer much of a decline in earnings. However, some subgroups of reemployed full-time job losers do suffer large earnings declines. This is particularly true for high-tenure job losers who may lose substantial specific human capital, making it difficult to find a new job that pays even close to earnings on the lost job. ${ }^{23}$

\section{Can Job Loss be a Good Thing for Some Workers?}

It is clear that the overall costs of job loss in the form of lost and lower earnings are very large. The primary cause is a reduction in hours of work. A substantial fraction of job losers are not reemployed at the subsequent DWS survey date (almost 35 percent in the most recent period, figure 10). By definition, all of these workers are earning less than they earned prior to the job loss. Even reemployed job losers take substantial time, on average, to find a job (about 12 weeks in the most recent period, figure 11), and (abstracting from any unemployment insurance benefits received) this implies substantial additional earnings losses. Additionally, a substantial fraction of reemployed full-time job losers are employed part-time (about 15 percent in the latest period, figure 12), and a very large fraction (at least 88 percent) of these are earning less on their new job than they earned on the lost job. Thus, average earnings losses are substantial.

However, the loss of a full-time job may be good for some workers, at least in the narrow sense that the job held subsequent to job loss may be better than the lost job, and I investigate this possibility here. For the purposes of this analysis, I define "better" to mean

\footnotetext{
${ }^{23}$ Kletzer (1989), Neal (1995), and Parent (2000) address the issue of job loss and specific capital, both at the firm and industry level.
} 
higher real weekly earnings on the new job relative to the lost job. But, given that earnings surely reported with error in the CPS/DWS, it is not straightforward to calculate the fraction with positive earnings changes. For example, if the true average real earnings change is negative and measurement error is classical (independent of true earnings, zero mean), then the presence of measurement error will cause the fraction of observed wage differences that are positive to overstate the fraction of true wage differences that are positive. In what follows, I lay out a simple representation of observed wages with measurement error and make a generous correction for measurement error (building on the work of Bound and Krueger (1991)) to adjust the observed fraction positive.

Suppose that actual log earnings of worker $i$ in period $t$ is $Y_{i t}^{*}$ but that these log earnings are observed with error $\eta_{i t}$ so that observed log earnings are ${ }^{24}$

$$
Y_{i t}=Y_{i t}^{*}+\eta_{i t} .
$$

The observed change in log earnings between the pre-loss job (period 0) and the post-loss job (period 1) is

$$
\Delta Y_{i}=\Delta Y_{i}^{*}+\left(\eta_{i 1}-\eta_{i 0}\right)=\left(Y_{i 1}^{*}-Y_{i 0}^{*}\right)+\left(\eta_{i 1}-\eta_{i 0}\right) .
$$

For the purposes of calculating a corrected fraction $\Delta Y^{*}$ positive, I proceed by assuming that true $\log$ weekly earnings are normally distributed with mean $\mu_{t}$ and variance $\sigma_{* t}^{2}$. I further assume that the measurement error is classical and normally distributed with mean zero and variance $\sigma_{\eta}^{2}$ and that the measurement error is uncorrelated with true earnings and uncorrelated over time.

The variance of the actual change in log earnings is $\sigma_{\Delta *}^{2}=\sigma_{* 1}^{2}+\sigma_{* 0}^{2}-2 \sigma_{* 01}$, where $\sigma_{* 01}$ represents the covariance of pre- and post-job-loss weekly earnings for worker $i$. The variance of the observed change in earnings is $\sigma_{\Delta}^{2}=\sigma_{\Delta *}^{2}+2 \sigma_{\eta}^{2}$. The variance of the observed earnings change exceeds the variance of the true earnings change by twice the measurement error variance. Note further that, since earnings of a given worker over time are positively correlated (even where there has been a job change), the true variance of the earnings change can be smaller than the variance of the earnings levels so that the signal to noise ratio in the observed earnings difference can be quite low.

\footnotetext{
${ }^{24}$ In order to use the earlier literature on measurement error in earnings, I base my analysis on the change in log real earnings rather than the change in the level of real earnings. Since the log is a monotone transformation of the level, identification of fraction positive earnings changes is unaffected by this analytic choice.
} 
Using the assumption of normality, the probability that an observed log earnings change is positive is

$$
P\left(\Delta Y_{i}>0\right)=1-\Phi\left[\frac{-\left(\mu_{1}-\mu_{0}\right)}{\sigma_{\Delta}}\right]=\Phi\left[\frac{\left(\mu_{1}-\mu_{0}\right)}{\sigma_{\Delta}}\right],
$$

where $\Phi[\cdot]$ represents the standard normal CDF. The average earnings change is generally negative so that $\left(\mu_{1}-\mu_{0}\right)<0$, and a larger variance implies a larger probability of a positive earnings change. The double dose of measurement error included in the variance of observed earnings changes means that the variance is overstated relative to the true variance of the earnings change. Noting that $\sigma_{\Delta *}^{2}=\sigma_{\Delta}^{2}-2 \sigma_{\eta}^{2}$, the probability that the true earnings change is positive is

$$
P\left(\Delta Y_{i}^{*}>0\right)=\Phi\left[\frac{\left(\mu_{1}-\mu_{0}\right)}{\sqrt{\sigma_{\Delta}^{2}-2 \sigma_{\eta}^{2}}}\right] .
$$

Clearly, the fraction positive among the reported earnings changes is a biased estimate of the fraction positive among true earnings changes. This bias is

$$
P\left(\Delta Y_{i}>0\right)-P\left(\Delta Y_{i}^{*}>0\right)=\Phi\left[\frac{\left(\mu_{1}-\mu_{0}\right)}{\sigma_{\Delta}}\right]-\Phi\left[\frac{\left(\mu_{1}-\mu_{0}\right)}{\sqrt{\sigma_{\Delta}^{2}-2 \sigma_{\eta}^{2}}}\right] .
$$

This bias is positive when the average earnings change is negative $\left(\mu_{1}-\mu_{0}<0\right)$, and the size of the bias increases with the variance of the measurement error $\left(\sigma_{\eta}^{2}\right)$.

In order to quantify the size of the bias in the fraction positive due to measurement error, I need estimates of relevant means and variances, all but one of which are observed in the DWS data. Those observed include $P\left(\Delta Y_{i}>0\right), \mu_{1}-\mu_{0}$, and $\sigma_{\Delta}$. The key missing parameter is the variance of the measurement error $\left(\sigma_{\eta}^{2}\right)$. I make generous estimates of this parameter based on the analysis of Bound and Krueger (1991), who used CPS earnings data from the March annual supplement matched to employer-reported Social Security earnings records in 1978 to estimate the extent of measurement error assuming that the Social Security earnings records were error free. Understanding that these data are very old by now and that the CPS underwent a substantial redesign in 1994 that may have affected the accuracy of the data collected, I use their estimates only to get an idea of the general magnitude of the measurement error.

I ignore certain features of their analysis, particularly their finding that measurement error in successive years is positively correlated. I do this for two reasons. First, it is likely that most of their CPS respondents in successive years are in the same job and so perceive compensation similarly over time and so make similar errors in reporting earnings, while my 
analysis of the DWS is for a group of workers, all of whom have changed jobs. Thus, it is likely that any temporal correlation in measurement error is smaller in the DWS. Second, my aim is to use a generous estimate of the measurement error variance in order to derive a lower-bound estimate of the probability of a positive earnings change for job losers. I also ignore their finding of a correlation between the measurement error and true (Social Security) earnings. Finally, I ignore their finding that men exhibit more measurement error in reported earnings than do women, and I adopt numbers for measurement error that are larger than even those found by Bound and Krueger for men in order to be conservative.

Table 4 of Bound and Krueger contains estimates for men of the covariance matrix of the components of observed log earnings. Specifically, I am interested in their finding that the measurement error variance for men's log earnings is about 20 percent of the size of the variance of true log earnings, which implies that the measurement error variance is about 17 percent of the variance of the log of self-reported earnings (including the measurement error). I proceed using the even more conservative assumption that the variance of the measurement error in levels is 20 percent of observed variance of log earnings (so that the measurement error is fully 25 percent of the variance of true log earnings).

Now consider what this degree of measurement error in reported earnings levels implies for the role of measurement error in the earnings change. As I noted earlier, the variance of the actual change in log earnings is $\sigma_{\Delta *}^{2}=\sigma_{* 1}^{2}+\sigma_{* 0}^{2}-2 \sigma_{* 01}$, where $\sigma_{* 01}$ represents the covariance of pre- and post-job-loss log weekly earnings for worker $i$. There is a strong positive correlation between old and new log earnings for reemployed full-time job losers ( $\rho=0.710)$. Assuming, as is close to what the data show, that the variances of pre- and post-job-loss observed log earnings levels are equal, using the correlation of 0.710 between pre- and post-earnings levels, and using the assumption that the measurement error variance is 25 percent of the true earnings variance, measurement error contributes fully 40 percent of the variance of the observed post-pre log earnings difference. This has the potential to introduce serious upward bias in the fraction of job losers with a positive earnings change.

The first row of table 3 contains statistics on the wage changes of reemployed full-time job losers. The average proportional earnings loss is relatively small at 5.6 percent, and 39 percent of observed wage changes are positive (column 3). Assuming that log wage changes are normally distributed (mean -0.164, s.d. 0.497), yields a predicted probability positive of 37 percent (column 4). But the bias from measurement error is substantial with an adjusted predicted probability positive of 28 percent (column 5). The second and third rows of table 3 contain the same statistics for full-time job losers separately for those reemployed full-time 
Table 3: Fraction of Reemployed Full-Time Job Losers with Positive Earnings Change

\begin{tabular}{|c|c|c|c|c|c|c|}
\hline Sample: & $\mathrm{N}$ & $\begin{array}{c}\text { Ave. Prop. } \\
\text { Wage Change } \\
\text { (s.d.) }\end{array}$ & $\begin{array}{c}(2) \\
\text { Ave log } \\
\text { Wage Change } \\
\text { (s.d.) }\end{array}$ & $\begin{array}{c}(3) \\
\% \text { Positive } \\
\text { Observed }\end{array}$ & $\begin{array}{c}(4) \\
\% \text { Positive } \\
\text { Predicted } \\
\text { No M.E. Adj. }\end{array}$ & $\begin{array}{l}(5) \\
\% \text { Positive } \\
\text { Predicted } \\
\text { M.E. Adj. }\end{array}$ \\
\hline FT Losers & 28875 & $\begin{array}{l}-0.056 \\
(0.412)\end{array}$ & $\begin{array}{l}-0.164 \\
(0.497)\end{array}$ & 0.391 & 0.371 & 0.281 \\
\hline FT-FT & 25315 & $\begin{array}{l}-0.007 \\
(0.391)\end{array}$ & $\begin{array}{l}-0.087 \\
(0.419)\end{array}$ & 0.429 & 0.418 & 0.317 \\
\hline FT-PT & 3560 & -0.406 & -0.717 & 0.116 & 0.132 & 0.080 \\
\hline
\end{tabular}

$(0.387) \quad(0.642)$

Note: Based on data from the 1984-2016 DWS. The observed fractions positive in column 3 are based simple tabulations of the observed difference in weekly earnings between the survey-date job and the lost job. The predicted fractions positive in column 3 are based on the assumption that the difference in weekly earnings is log-normal and calculated using the observed mean and variance of the difference in log weekly earnings. The measurement error adjusted predicted fractions positive in column 5 are based on the assumption of log-normality and an additional assumption that observed level of log earnings contain measurement error such that the variance of the measurement error is 20 percent of the observed variance of log earnings. The sample is trimmed by deleting the smallest and largest one percent of observed earnings changes. See text for more details.

and those reemployed part-time respectively. Not surprisingly, the positive earnings changes are concentrated among those full-time job losers who are reemployed in a full-time job. The average proportional earnings change is close to zero, and 43 (42) percent of job losers making a FT-FT transition were observed (predicted) to have a positive earnings change. This falls to 31.7 percent after the adjustment for measurement error. Positive earnings changes are rare among full-time job losers who are reemployed in a part-time job (row 3 of the table). Their average earnings change is -41 percent, and 11.6 (13.2) percent are observed (predicted) to have a positive earnings change. This falls to 8.1 percent after the adjustment for measurement error.

It is somewhat surprising that, even after a liberal adjustment for measurement error, a substantial fraction of full-time job losers who are successful at finding a new full-time job earn more on their new job than on the job they lost. There is surely substantial heterogeneity across job losers in the likelihood of their finding a new job that pays more than the lost job. In order to investigate this, I use the variation in wage changes associated with worker demographics highlighted in table 2 to calculate measurement error adjusted probabilities of a positive earnings change associated with job loss for job losers of various characteristics making a FT-FT transition. I begin showing variation by year in the top panel of figure 14, and the temporal variation is weakly cyclical. The fraction of job losers making a FT-FT 

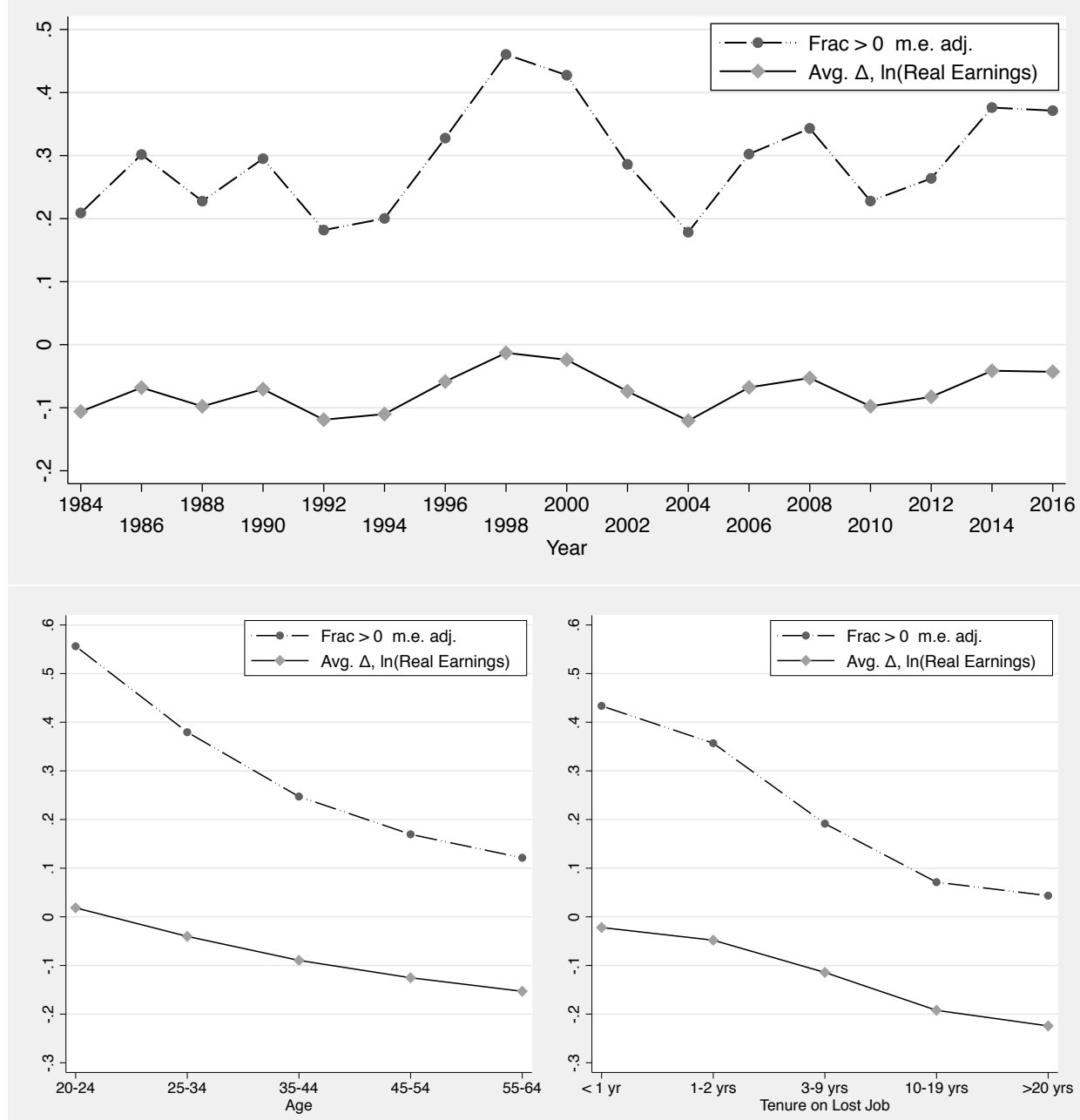

Source: Displaced Workers Survey, 1984-2016

Figure 14: Fraction Positive Real Earnings Change for Job Losers Making FT-FT Transition, Measurement Error Adjusted, by Year, Age, and Tenure on Lost Job

transition who had a positive earnings changes was highest (over 40 percent) in the strong labor market of the mid- to late 1990s. This reflects the near zero average log wage change during this period. The fraction of those making a FT-FT transition who had a positive earnings change was lowest (under 20 percent) in the earlier 1990s recession and in the early 2000s, slightly higher (just above 20 percent) in the Great Recession, and has been rising since (to almost 40 percent) in 2014 and 2016. It is, of course, the case that these time series movements in the fraction with positive earnings changes reflect movements over time in the average change in log real wages (also shown in the figure).

The most important dimensions along which the average change in real wages varied are 
age and tenure on the lost job. The panels in the second row of figure 14 contain similar plots of the fraction of job losers making a FT-FT transition who have a positive real earnings change broken down by age (left hand plot) and tenure on the lost job (right hand plot). Consider age first. The fraction with positive earnings changes declines sharply with age, falling from over 50 percent for job losers 20-24 years old to about 10 percent of job losers 55-64. This mirrors an increase in the average decline in log real earnings from zero for the youngest job losers to $16 \log$ points for the oldest job losers. The decline is also very sharp with tenure on the lost job, where the fraction with positive earnings changes falls from about 43 percent of job losers in their first year on the lost job to about 4 percent of job losers with at least 20 years of tenure on the lost job. Again, this mirrors an increase in the average decline in log real earnings from close to zero for workers with little tenure to losers to $22 \log$ points for workers in the highest tenure category.

Age and tenure are certainly positively correlated, and the relationships shown in figure 14 are strictly bivariate. One possibility is that only one of age or tenure is driving the negative relationships of the fraction with positive earnings changes with these variables. However, the multivariate analysis of proportional wage changes shown in the fourth column of table 2 for job losers making a FT-FT transition show that significant negative effects of both age and tenure remain. These estimates imply a difference in the average real wage change between the youngest and oldest job losers of about 14 percentage points controlling for tenure. Coincidentally, I find a similar 14 percentage point difference in the real wage change between the least tenured and most tenured job losers controlling for age. Clearly, both older and more highly tenured full-time job losers suffer larger earnings declines and are less likely to earn more on their new full-time job.

The finding that many job losers, particularly those who are younger and have not been on their job for long, find a higher paying job raises the interesting question of why it is they did not quit their original jobs and take the new higher-paying jobs voluntarily. Why did they need the "kick in the rear" of job loss in order to take these new higher-paying job? There are some obvious and not-so-obvious answers to these questions.

- Importantly, the new job may not be better than the lost job (not yield higher utility than the lost job) despite offering higher earnings. There are many job attributes that are relevant to the job choice decision. A few of these include general interest, opportunities for advancement, the nature of coworkers, the commute, hours, and fringe benefits.

- Job change can be costly. Search is not easy or costless. It takes time, during which 
the individual is not employed and, hence, not earning. Individuals may have to move to take a new job. It is worth noting that the two groups of job losers who are most likely to earn more on their new job (younger and less tenured workers) are among those with the highest post-loss employment rates and the shortest time to find a new job (table 1). Even so, it is likely that the cost of job change can be large.

- If workers are risk averse with respect to the uncertainties surrounding new employment they may not be willing to change voluntarily to a new job that, ex post, turns out to offer higher earnings and utility. And, if workers are loss averse, the possibility that a new job may result in a loss is even more likely to outweigh an expected gain in pay.

- Coming at it from a different angle, there is some recent experimental work (Levitt 2016) suggesting that individuals may be reluctant to make important life changes generally, including quitting a job, that result in a higher reported ex post level of happiness on average. This suggests that encouraging some workers to change jobs could result in higher utility. In other words, job loss may be good for a minority of workers.

\section{Concluding Remarks}

My estimates of the costs of job loss based on the DWS show that displacement imposes a significant economic burden on job losers. The first part of these costs are in the form of difficulty in finding new employment and, importantly, difficulty in finding full-time employment. This component of costs was particularly severe for workers losing jobs in the Great Recession, when less than 50 percent of full-time job losers reported being employed at the next DWS survey date (January 2010). And 20 percent of these full-time job losers who did find jobs were employed part-time at the survey date.

Importantly, the adverse employment experience of full-time job losers continued beyond the Great Recession. While employment rates and full-time employment rates improved, those who lost jobs even two to four years after the Great Recession (2011-2013) had low employment rates and low full-time employment rates by historical standards. This is consistent with the rather slow decline in the unemployment rate and the continuing high level of long-term unemployment in the aftermath of the Great Recession. The long run consequences of the decreased ability to find employment subsequent to job loss and resulting long spells of unemployment may be self-reinforcing in that some of these job losers, perhaps by 
being scarred by a long spell of unemployment or simply perceived by employers as less able workers, may have serious long-run difficulty in finding work. ${ }^{25}$

My analysis of the DWS shows modest average weekly earnings declines for reemployed full-time job losers who are able to find a new full-time job, and these average earnings declines were not especially large by historical standards in the Great Recession or its aftermath. However, focusing on the average earnings decline masks substantial heterogeneity across workers, with older and more tenured job losers suffering substantial earnings losses. Interestingly, a substantial fraction of full-time job losers who are reemployed full-time are earning more in real terms on their new job than on the lost job, with the "winners" concentrated among younger and less tenured job losers.

The earnings declines I estimate generally are smaller than those that are derived using administrative data. ${ }^{26}$ This is true for several reasons. Importantly, the concept of earning change that I estimate using the DWS, weekly earnings for full-time workers, is more like a wage rate. In contrast, the administrative data, typically from UI or Social Security records, records quarterly earnings. Quarterly hours are likely be quite variable across weeks within a quarter relative to the weekly hours of a full-time worker, particularly after a job loss. Immediately after job loss, there will be whole or part quarters during which workers are without jobs. Additionally, the earnings loss measure from administrative data includes the loss in quarterly earnings that comes from a move from full-time to part-time employment that is a consequence of job loss I document using the DWS. And, to the extent that the employment experience of workers subsequent to job loss is less secure, there are likely to be partial quarters of non-employment even later. The result will be continued lower earnings that are due to lower hours worked as well as potentially lower weekly earnings when employed full time.

The earnings decline measure from the DWS is appropriate for understanding how job loss affects the earnings that a full-time employed former job-loser is able to command (essentially

25 The evidence on this question from a set of recent audit studies is mixed. Kroft, Lange, and Notowidigdo (2013) find that the callback rate for job applications "submitted by" younger workers (less than 35 years of age) is negatively related to the duration of unemployment. However, Nunley, et. at. (2014) do not find such a relationship for young college educated workers, and Farber, Silverman, and Von Wachter (2016) find no such relationship for older workers. Eriksson and Rooth (2014) find that call-backs are, at best, weakly negatively related to unemployment duration in a Swedish audit study.

26 The large earnings losses found in administrative data were highlighted by Jacobsen, LaLonde, and Sullivan (1993). von Wachter, Handwerker, and Hildreth (2009) explicitly investigate reasons why the DWS and administrative data from California in the 1990s seem to yield different measures of earnings loss. Couch and Placzek (2010) and Davis and von Wachter (2011) are other examples of relatively large estimates of earning loss after displacement. 
a wage rate). This is important for understanding a range of important issues. One example is the relationship between earnings loss and tenure focusing on the potential importance of specific capital (Kletzer, 1989; Topel, 1990; Neal, 1995; Parent, 2000). However, the DWS measure of weekly earnings change alone does not capture the full earnings cost of job loss because it does not account for time spent by a full-time job loser without a job or time spent working part-time until a full-time job is found.

To conclude, while job loss is a fact of life in the U.S., the employment consequences of job loss in the Great Recession have been unusually severe and remain substantial years later. Most importantly, job losers in the Great Recession and its aftermath have been much less successful at finding new jobs (particularly full-time jobs) than in earlier periods. The decreased ability of full-time job losers in recent years to find new full-time employment reinforces the findings from studies of job loss using administrative data that job loss has long run adverse consequences for employment and earnings. However, my analysis suggests there are winners and losers among displaced workers. The "winners" are those who find new full-time employment without much delay and earn more on the new job (generally younger and lower tenure job losers). But the majority of displaced workers are "losers" in that they have difficulty finding new full-time employment and earn less subsequently. 


\section{References}

Abraham, Katharine G. and James L. Medoff. "Length of Service and Layoffs in Union and Nonunion Work Groups," Industrial and Labor Relations Review 38 (October 1984): $87-97$.

Bewley, Truman. Why Wages Don't Fall During a Recession, Harvard University Press, 1999.

Bound, John and Alan B. Krueger. "The Extent of Measurement Error in Longitudinal Earnings Data: Do Two Wrongs Make a Right?" Journal of Labor Economics 9(1) (January 1991): 1-24.

Chodorow-Reich, Gabriel and Loukas Karabarbounis. "The Cyclicality of the Opportunity Cost of Employment," Journal of Political Economy, in press, 2016.

Couch, Kenneth A. and Dana W. Placzek. "Earnings Losses of Displaced Workers Revisited." American Economic Review 100(1) (2010): 572-589.

Davis, Steven J. and Till Von Wachter, 2011. "Recessions and the Costs of Job Loss," Brookings Papers on Economic Activity 43(2) (2011): 73-119.

de la Rica, Sara. "Displaced Workers in Mass Layoffs: Pre-Displacement Earnings Losses and the Unions Effect," Working Paper No. 303, Industrial Relations Section, Princeton University, June 1992.

Eriksson, Stefan and Dan-Olof Rooth. "Do employers use unemployment as a sorting criterion when hiring? Evidence from a field experiment," American Economic Review, 104 (2014), 1014-1039.

Fallick, Bruce C. "A Review of the Recent Empirical Literature on Displaced Workers," Industrial and Labor Relations Review 50 (October 1996): pp. 5-16.

Farber, Henry S. "The Changing Face of Job Loss in the United States, 1981-1995," Brookings Papers on Economic Activity: Microeconomics, 1997: 55-128.

Farber, Henry S. "Mobility and Stability: The Dynamics of Job Change in Labor Markets." In Ashenfelter and Card, eds. The Handbook of Labor Economics, vol 3B, pp. 24392484, North Holland Publishing Company, 1999.

Farber, Henry S. "Job Loss in the United States, 1981-2001," Research in Labor Economics 23 (2004), pp. 69-117. 
Farber, Henry S. "Is the 'Company Man' an Anachronism? Trends in Long Term Employment in the U.S." in The Price of Independence, Sheldon Danziger and Cecilia Rouse, eds. Russell Sage, 2007, pp. 56-83.

Farber, Henry S. "Job Loss: Historial Perspective from the Displaced Workers Survey." in Unexpected Lifecycle Events and Economic Security: the Roles of Job Loss, Disability, and Changing Family Structure, Kenneth A. Couch, Mary C. Daly, and Julie Zissimopoulos, eds., Stanford University Press, 2013, pp. 11-33.

Farber, Henry S. "Job Loss in the Great Recession and its Aftermath: U.S. Evidence from the Displaced Workers Survey." Working Paper 21216, National Bureau of Economic Research, May 2015.

Farber, Henry S., Dan Silverman, and Till von Wachter. "Determinants of Callbacks to Job Applications: An Audit Study," American Economic Review, 106(5) May 2016, pp. 314-318.

Gardner, Jennifer M. "Worker Displacement: A Decade of Change," Monthly Labor Review 118 (April 1995): pp. 45-57.

Hagedorn, M., and I. Manovskii. "The Cyclical Behavior of Equilibrium Unemployment and Vacancies Revisited," American Economic Review, 98(4) 2008, pp. 169270.

Hipple, Steven. "Worker Displacement in the mid-1990's," Monthly Labor Review 122 (July 1999): pp. 15-32.

Jacobsen, Louis, Robert LaLonde, and Daniel Sullivan. "Earnings Losses of Displaced Workers," American Economic Review 83 (September 1993): pp. 685-709.

Jovanovic, Boyan. "Job Matching and the Theory of Turnover", Journal of Political Economy, 87 (1979), 972-990.

Kletzer, Lori G. "Returns to Seniority after Permanent Job Loss," American Economic Review 79 (June 1989): pp. 536-543.

Kroft, Kory, Fabian Lange, and Matthew J. Notowidigdo. "Duration Dependence and Labor Market Conditions: Evidence from a Field Experiment," Quarterly Journal Of Economics (2013): pp. 1123-1167.

Lahey, Joanna N. "Age, Women, and Hiring: An Experimental Study," Journal of Human Resources 43 (2008): pp. 30-56. 
Levitt, Steven D. "Heads or Tails: The Impact of a Coin Toss on Major Life Decisions and Subsequent Happiness," Working Paper No. 22487, National Bureau of Economic Research, August 2016.

National Bureau of Economic Research. "The NBER's Business Cycle Dating Committee," September 20, 2010. Available at http://www.nber.org/cycles/recessions.html

Neal, Derek. "Industry-Specific Capital: Evidence from Displaced Workers," Journal of Labor Economics 13 (October 1995): pp. 653-677.

Neumark, David, Ian Burn, and Patrick Button. "Is it Harder for Older Workers to Find Jobs? New and Improved Evidence from a Field Experiment." Working Paper No. 21669, National Bureau of Economic Research, October 2015.

Nunley, John M., Adam Pugh, Nicholas Romero, and Richard Alan Seals, Jr., "Unemployment, Underemployment, and Employment Opportunities: Results from a Correspondence Audit Study of the Labor Market for College Graduates." forthcoming, Industrial and Labor Relations Review.

Parent, Daniel. "IndustrySpecific Capital and the Wage Profile: Evidence from the National Longitudinal Survey of Youth and the Panel Study of Income Dynamics, "Journal of Labor Economics 18 (April 2000): pp. 306-323.

Podgursky, Michael and Paul Swaim. "Job Displacement Earnings Loss: Evidence from the Displaced Worker Survey,"” Industrial and Labor Relations Review 41 (October 1987): pp. 17-29.

Polivka, Anne E. and Stephen M. Miller. "The CPS After the Redesign: Refocusing the Lens," in Labor Statistics Measurement Issues, John Haltiwanger, Marilyn Manser, and Robert Topel, eds., University of Chicago Press, 1998. pp. 249-289.

Schmeider, Johannes and Till von Wachter. "Does Wage Persistence Matter for Employment Fluctuations? Evidence from Displaced Workers," American Economic Journal: Applied Economics 2 (2010): pp. 1-21.

Song, Jae and Till von Wachter. "Does Wage Persistence Matter for Employment Fluctuations? Evidence from Displaced Workers," mimeo, September 2014.

Topel, Robert. "Specific Capital and Unemployment: Measuring the Costs and Consequences of Job Loss," Carnegie Rochester Conference Series on Public Policy 33 (1990): pp. 181-214. 
Valletta, Robert G., Leila Bengali, and Catherine van der List. "Cyclical and Market Determinants of Involuntary Part-Time Employment," Working paper 2015-19, Federal Reserve Bank of San Francisco, December 2015.

von Wachter, Till, Elizabeth Weber Handwerker, and Andrew K.G. Hildreth. "Estimating the 'True' Cost of Job Loss: Evidence Using Matched Data from California 1991-2000." Working Paper CES 09-14, U.S. Bureau of the Census, Center for Economic Studies, June 2009. 